Western University

Scholarship@Western

Earth Sciences Publications

Earth Sciences Department

2016

\title{
Early Horizon Camelid Management Practices in the Nepeña Valley, North-central Coast of Peru
}

Paul Szpak

The University of Western Ontario

David Chicone

Louisiana State University

Jean-François Millaire

The University of Western Ontario

Christine D. White

The University of Western Ontario

Rebecca Parry

The University of Western Ontario

See next page for additional authors

Follow this and additional works at: https://ir.lib.uwo.ca/earthpub

Part of the Biological and Physical Anthropology Commons, and the Earth Sciences Commons

Citation of this paper:

Szpak, Paul; Chicone, David; Millaire, Jean-François; White, Christine D.; Parry, Rebecca; and Longstaffe, Fred, "Early Horizon Camelid Management Practices in the Nepeña Valley, North-central Coast of Peru" (2016). Earth Sciences Publications. 12.

https://ir.lib.uwo.ca/earthpub/12 
Authors

Paul Szpak, David Chicone, Jean-François Millaire, Christine D. White, Rebecca Parry, and Fred Longstaffe 


\section{Early Horizon Camelid Management Practices in the Nepeña Valley, North-Central Coast of Peru}

Paul Szpak $^{\mathrm{a}^{*}}$, David Chicoine ${ }^{\mathrm{b}}$, Jean-François Millaire ${ }^{\mathrm{a}}$, Christine D. White ${ }^{\mathrm{a}}$, Rebecca Parry $^{\mathrm{a}}$, Fred J. Longstaffe ${ }^{\mathrm{c}}$

a Department of Anthropology, The University of Western Ontario, London, Ontario N6A 5C2, Canada

${ }^{\mathrm{b}}$ Department of Geography and Anthropology, Louisiana State University, Baton Rouge, Louisiana 70803, USA

${ }^{c}$ Department of Earth Sciences, The University of Western Ontario, London, Ontario N6A 5B7, Canada

* Corresponding Author, present address: Department of Anthropology, The University of British Columbia, Vancouver, British Columbia V6T 1Z1, Canada

Revised Version, Prepared For: Environmental Archaeology 6 Figures, 1 Table, 1 Supplement 


\section{Abstract}

2 South American camelids (llamas and alpacas) were of great economic, social, and ritual

3 significance in the prehispanic Andes. Although these animals are largely limited to high altitude

$4 \quad(>3,500$ masl) pastures, it has been hypothesized that camelids were also raised at lower altitudes

5 in the arid coastal river valleys. Previous isotopic studies of Early Intermediate Period (c. 200

6 BC to AD 600) and Middle Horizon (c. AD 600 to 1100) camelids support this argument. Here,

7 we utilize carbon and nitrogen isotopic analyses of camelid bone collagen from the Early

8 Horizon (c. 800 to 200 BC) sites of Caylán and Huambacho on the north-central coast of Peru to

9 examine the management of these animals during the first millennium BC. Most of the camelid

10 isotopic compositions are consistent with the acquisition of animals that were part of caravans,

11 moving between the coast and the highlands. A small number of the animals may have been

12 raised on the coast, suggesting that the practice of coastal camelid husbandry was in the

13 experimental phase during the Early Horizon before growing into a more established practice in

14 the Early Intermediate Period. These results echo zooarchaeological studies from the region that

15 have revealed a paucity of camelid remains in refuse deposits prior to $800 \mathrm{BC}$, followed by an

16 increase in abundance after $450 \mathrm{BC}$.

18 Keywords: Stable isotopes; Carbon; Nitrogen; Animal husbandry; Andes; Llama; Caravan;

19 Exchange 


\section{Introduction}

23 In the Americas, the South American camelids (llama [Lama glama] and alpaca [Vicugna

24 pacos]) were the only large mammalian species to be domesticated. While there was temporal

25 and regional variability, these animals were utilized for their meat (Pozorski 1979a; Miller and

26 Burger 1995; Marcus et al. 1999), wool (Murra 1962; Boytner 2004; Millaire 2008), dung (for

27 fuel and fertilizer) (Winterhalder et al. 1974; Grossman 1983; Bruno 2014), and as pack animals

28 (Browman 1975; Stahl 1988; deFrance 2010). Camelids figured prominently in iconographic

29 representations (Shimada and Shimada 1985; Stone-Miller 1992) and ceremonial events (Donnan

30 and Foote 1978; Millaire 2002; Goepfert 2012; Szpak et al. 2014; Millaire 2015; Szpak et al. In

31 Press). They permeated every aspect of life in the pre-Hispanic Andes and were thus intimately

32 intertwined with political, religious, and social developments in the region. Accordingly,

33 understanding camelid management practices, as well as the interactions between people and

34 these animals is critical in the context of Andean prehistory.

35 After the arrival of the Spanish in the sixteenth century various aspects of camelid

36 management were recorded (Murra 1965, 1968, 1980). Yet, many questions remain surrounding

37 the broader applicability of these models across both time and space. Overall, animal

38 management practices prior to the Late Horizon (A.D. 1476 to 1532) are particularly poorly

39 understood. This is due largely to the fact that traditional agro-pastoral systems were severely

40 disrupted by the Spanish conquest in the sixteenth century (Gade 1992). Moreover, the number

41 of camelids, as well as their range was substantially reduced and, in many places, European

42 domesticates (pig, sheep, and donkey) began to overshadow camelids in terms of economic

43 importance (Wheeler 1995). 
On the basis of ethnographic and ethnohistoric accounts, camelid herding was principally

45 associated with the high altitude ( $>3,500$ masl) pastures of the altiplano and puna (Gilmore

46 1950; Murra 1962, 1965, 1968; Browman 1974; Winterhalder et al. 1974; Orlove 1977b; Flores-

47 Ochoa 1979; Murra 1980; Orlove 1982; McCorkle 1987; Flannery et al. 1989; Browman 1990a,

48 b; Kuznar 1991). This is the environment in which camelid pastoralism originated (Wheeler

49 1985; Browman 1989; Kuznar 1989; Moore 1989; Wheeler 1995; Aldenderfer 2001) and the

50 nature of management in the highlands has been widely examined in archaeological contexts

51 (Browman 1984; Moore 1988; Webster 1993; Moore et al. 1999; Duncan 2003; Webster and

52 Janusek 2003; Aldenderfer 2006; Beaule 2012; Knudson et al. 2012; Vallières 2012). Camelids

53 are, however, regularly present in refuse and ceremonial deposits at sites on the north, central,

54 and south coasts of Peru from at least the Early Horizon (c. 800 BC) and through to the Late

55 Horizon (c. AD 1476 to 1532) (Pozorski 1979a; Pozorski 1979b; Reitz 1979; Shimada and

56 Shimada 1985; Marcus et al. 1999; Bonavia 2008; Chicoine 2011; Goepfert 2012; Millaire

57 2015). Some scholars have argued that camelids (specifically llamas) were raised locally along

58 the coast, rather than being imported from higher altitudes either as dried meat (ch'arki or jerky)

59 or meat on the hoof via coast-highland networks of llama caravans. In the most comprehensive

60 summary of various lines of evidence for coastal camelid herding, Shimada and Shimada (1985)

61 argued that this practice was established by the onset of the Middle Horizon (c. AD 600) on the

62 north coast of Peru and suggested it may have started as early as the Early Horizon (c. 800 BC).

63 With the exception of neonates, however, the presence of camelid remains at coastal sites can be

64 difficult to interpret as unambiguous evidence for local herding. Hence, the presence of camelid

65 skeletal remains on the coast alone cannot be used as definite indicator of local herding. 
Because of the large environmental and phytogeographic differences between the coastal

67 and high altitude regions of Peru and associated differences in plant isotopic compositions

68 (Szpak et al. 2013), stable isotope analyses have been employed to assess the question of

69 camelid husbandry outside the highlands (DeNiro 1988; Verano and DeNiro 1993; Thornton et

70 al. 2011; Dufour et al. 2014; Szpak et al. 2014; Szpak et al. 2015; Szpak et al. In Press).

71 Generally, a pattern emerges in which animals recovered from coastal contexts are characterized

72 by significantly higher dietary contributions of $\mathrm{C}_{4}$ plants (likely maize) relative to camelids from

73 the highlands, as well as greater inter-individual isotopic variability. This pattern is clearly

74 manifested at several sites on the north coast of Peru during the Early Intermediate Period

75 (beginning c. 200 BC), which strongly suggests coastal based camelid husbandry by this time

76 (Dufour et al. 2014; Szpak et al. 2014; Szpak et al. In Press). It is, however, unclear whether or

77 not coastal camelid husbandry predates the EIP and the emergence of what have been

78 characterized as archaic states on the north coast of Peru (Fogel 1993; Millaire 2010;

79 Chapdelaine 2011). Presently, the only pre-EIP isotopic data that exist for coastal camelids come

80 from three individuals from La Paloma (5800-1800 BP) on the southern central coast of Peru

81 (DeNiro 1988) but their precise context is not clear. The purpose of this study is to analyze the

82 isotopic compositions of camelid bone collagen from Caylán and Huambacho, two Early

83 Horizon settlements located in the coastal portion of the Nepeña Valley to assess whether or not

84 the previously observed isotopic patterns of coastal camelid management can be traced back to

85 the first millennium BC.

86

87 Isotopic Context 
The western slope of the Peruvian Andes is a region of marked environmental variation.

89 As altitude increases moving from the arid coastal desert, mean daily temperature decreases and

90 mean annual precipitation increases (Troll 1968; Sandweiss and Richardson 2008).

91 Consequently, the carbon and nitrogen isotopic compositions of vegetation vary in accordance

92 with altitude, and the low (coastal) and high altitude regions are isotopically distinct (Szpak et al.

93 2013). This is true in terms of wild plants and to a lesser extent for domestic plants. On the coast

94 and at low altitudes, where conditions are relatively warm and dry, $\mathrm{C}_{4}$ plants occur regularly. The

95 high altitude habitats associated with modern camelid herding are generally devoid of $\mathrm{C}_{4}$ species,

96 with the exception of Muhlenbergia sp., which has been recorded in some highland pastures.

97 Nevertheless, these plants are not especially abundant (Wilcox et al. 1987) and constitute a

98 relatively minor fraction (no more than $15 \%$ and usually much less) of camelid forage today

99 (Bryant and Farfan 1984; Reiner and Bryant 1986).

100 On the basis of the isotopic ecology of the western slope of the Andes (Szpak et al.

101 2013), as well as previous isotopic studies of camelids, we can generate a series of expectations

102 with respect to camelid isotopic compositions to assess whether or not they were herded in a

103 particular ecological zone, which are summarized in Figure 1. These approximations are

104 intended to represent isotopic data derived from bone collagen, which continuously turns over

105 and therefore represents an average of the long-term diet (Wild et al. 2000). As with nearly all

106 species, controlled studies examining the turnover rates of bone collagen in camelids have not

107 been performed. Based on estimates of turnover rates in human bone collagen (upwards of 20

108 years; Stenhouse and Baxter 1979; Wild et al. 2000; Hedges et al. 2007), however, it is

109 reasonable to assume that the isotopic composition of camelid bone collagen reflects a lifetime

110 average of diet. Therefore, collagen lacks the ability to resolve more precise life histories relative 
111 to tissues that grow continuously such as hair (Szpak et al. 2014) or tissues that may be sampled

112 along growth axes such as teeth (Dufour et al. 2014).

113 For camelids herded on the high altitude pastures of the puna and altiplano, we expect

114 low carbon isotopic compositions, consistent with diets composed principally $(>80 \%)$ of $\mathrm{C}_{3}$

115 plants. Nitrogen isotopic compositions are relatively difficult to predict because the pastures on

116 which camelids graze in the Andean highlands may be relatively wet (e.g., the bofedales

117 [cushion-peat bogs] and moist punas that occur in the central Peruvian highlands) or dry (e.g.,

118 the dry and salt punas that occur primarily in southern Peru and further south, east of the

119 Atacama) (Baied and Wheeler 1993). Given that plant tissue $\delta^{15} \mathrm{~N}$ values tend to be higher in

120 under conditions of limited water availability (Handley et al. 1999; Amundson et al. 2003;

121 Craine et al. 2009), we would expect high $\delta^{15} \mathrm{~N}$ values in dry relative to moist highland pastures,

122 although this requires experimental verification.

123 While comparatively few modern camelids from high altitude contexts (both modern and

124 archaeological) have been subjected to isotopic analysis, none have been characterized by the

125 high (>8\%) nitrogen isotopic compositions that have been recorded for some camelids from

126 coastal and low altitude sites (DeNiro 1988; Verano and DeNiro 1993; Thornton et al. 2011;

127 Dufour et al. 2014; Szpak et al. 2014; Szpak et al. 2015). A pattern of camelid diets dominated

128 by $\mathrm{C}_{3}$ plants has been recorded for modern camelids from high altitude contexts throughout

129 much of Peru (Schoeninger and DeNiro 1984; Thornton et al. 2011; Dufour et al. 2014; Szpak et

130 al. 2014), as well as archaeological camelids from Chinchawas (3,850 masl) (Szpak et al. 2015)

131 and Tiwanaku (3,800 masl) (Szpak 2013). For camelids that were herded on the coast, we predict

132 three different patterns depending on whether the principle forage was agricultural fodder (e.g., 
133 maize and other byproducts) or wild plants, and the scale at which herding was practiced (large

134 or small herds).

135 For camelids herded on the coast or at low altitudes that grazed on wild vegetation, we

136 expect high carbon isotopic compositions (due to a higher proportion of $\mathrm{C}_{4}$ plants in the diet) and

137 much higher nitrogen isotopic compositions (due to the consumption of vegetation growing

138 under water-limited conditions) relative to high altitude camelids. Because the coastal and low

139 altitude regions still contain appreciable quantities of $\mathrm{C}_{3}$ plants, relatively low carbon isotopic

140 compositions are still feasible, although most of these plants should still be characterized by high

141 nitrogen isotopic compositions because of the aridity effects on vegetation (Szpak et al. 2013).

142 These patterns have been observed in camelids from several sites, although not necessarily

143 interpreted in this manner: Cerro Baul in the Moquegua Valley (2,500 masl) (Thornton et al.

144 2011), as well as Chilca and La Paloma on the southern central coast of Peru (DeNiro 1988).

145 The coast of Peru is essentially a desert environment with areas of herbaceous vegetation

146 being more common in coastal river valleys, which today may support small numbers of grazing

147 goats in some areas (Rundel et al. 1991). The lack of substantial vegetation on the coast is,

148 however, a potential limitation to the herding of camelids. Accordingly, it has been suggested

149 that coastal camelids would have been provided with principally, or entirely, fodder from

150 agricultural products or byproducts. This is an important distinction in terms of animal

151 management practices, and the consumption of coastal cultigens should manifest itself

152 differently in camelid tissue isotopic compositions relative to the consumption of wild coastal 153 vegetation.

154 On the coast of Peru rainfall occurs only under exceptional circumstances and agriculture 155 is entirely dependent on irrigation (Rauh 1985). Because of this, cultigens are not subjected to 
156 the water-limited conditions characteristic of wild coastal vegetation and the influence of local

157 environmental conditions on plant $\delta^{15} \mathrm{~N}$ values is mediated (Szpak et al. 2012a). Therefore,

158 coastal camelids provided with agricultural fodder will not be characterized by unusually high

$159 \delta^{15} \mathrm{~N}$ values. Nevertheless, $\mathrm{C}_{4}$ cultigens are much more common at lower altitude and coastal

160 sites relative to those in traditional camelid herding areas, which instead focus on tuber (all of

161 which are $\mathrm{C}_{3}$ plants) cultivation (Orlove and Godoy 1986). Therefore, unlike low altitude

162 camelids grazing on wild vegetation, coastal camelids foddered with agricultural byproducts

163 should be characterized by relatively high, but variable, carbon isotopic compositions (due to the

164 importance of maize foddering), but nitrogen isotopic compositions that are comparable to

165 camelids herded in highland pastures. Such a pattern has been observed at many sites along the

166 north coast of Peru including Huaca Gallinazo, Huaca Santa Clara, and Huancaco in the Virú

167 Valley (Szpak et al. 2014), Pacatnamú in the Jequetepeque Valley (Verano and DeNiro 1993),

168 and El Brujo in the Chicama Valley (Dufour et al. 2014). It is important to point out that the

169 sample sizes for the latter two sites were quite small, making it difficult to formulate any broad

170 generalizations about camelid diets.

171 A third pattern involves intensive foddering of camelids with maize. In this case,

172 camelids are still fed agricultural products or byproducts but consume a markedly less varied diet

173 at the group or population level and would be characterized by consistently high $\delta^{13} \mathrm{C}$ values.

174 Evidence for intensive maize foddering has been recorded at Conchopata (2,700 masl) where

175 several camelids (interpreted to be llamas) had $\delta^{13} \mathrm{C}$ values of c. $-10 \%$ (Finucane et al. 2006).

176 This pattern is not necessarily specific to any particular region, but the fact that maize is not

177 cultivable above c. 3,500 masl (Sandweiss and Richardson 2008) and $\mathrm{C}_{4}$ plants are also sparsely

178 distributed above this altitude (Szpak et al. 2013) precludes this camelid management strategy 
179 from the puna. To date Conchopata is the only site where these isotopic compositions have been

180 observed, although it is important to note that the $\delta^{13} \mathrm{C}$ values were bimodally distributed and it is

181 unclear whether a larger sample from the site would have obscured this pattern and produced a

182 dataset more similar to others from sierra and coastal sites.

\section{Archaeological Context and Materials}

185 Nepeña is a small coastal oasis located $400 \mathrm{~km}$ north of Lima (Figure 2). The valley is

186 perhaps most famous for its strong human presence and dynamic cultural innovations during the

187 first millennium BC (Proulx 1982; Daggett 1983, 1984). During the local Nepeña Phase (800-

188450 cal BC, Figure 3) (see Shibata 2011), late Initial Period ceremonial centers such as Cerro

189 Blanco and Huaca Partida were abandoned and populations gradually nucleated at urban-like

190 settlements on the north and south margins of the valley. Survey and excavation work over the

191 last decade indicate that these developments were associated with the rise of an Early Horizon

192 polity based at the primary center of Caylán, the largest archaeological complex in Nepeña

193 (Chicoine and Ikehara 2010, 2014).

194 Caylán is located on the northern margin of the lower valley, some $15 \mathrm{~km}$ from the

195 Pacific coastline. The site appears strategically located at the center of the catchment area of the

196 lower valley polity. Meanwhile, secondary satellite communities in the lower valley have been

197 recorded at Huambacho (Chicoine 2006), Sute Bajo (Cotrina et al. 2013), Samanco (Helmer and

198 Chicoine In Press), and perhaps Cerro Blanco (Shibata 2010, 2011). Radiocarbon dates indicate

199 that the polity reached its climax during the local Samanco Phase (450-150 BC), before giving

200 way to outside influences at the turn of the first millennium AD (Chicoine 2011). 
202 secure excavated contexts at Cerro Blanco (Ikehara et al. 2013), Huambacho (Chicoine 2011;

203 Chicoine and Rojas 2012), and Caylán (Chicoine and Rojas 2013; Chicoine et al. In Press) have

204 provided insight into the profound socioeconomic transformations experienced by Early Horizon

205 groups in coastal Nepeña. Most salient among these transformations are the extension of

206 irrigation networks, the intensification of maize cultivation, and the increased reliance on

207 highland animal domesticates - namely guinea pigs and camelids. Previous research suggests

208 that these innovations were closely tied to a reorganization of exchange networks, shifts in

209 leadership strategies, heightened elite competition as materialized in the acquisition of prestige

210 items, the construction of more exclusive ritual settings, and the sponsoring of feasts and alcohol

211 production (Chicoine 2011; Ikehara et al. 2013). While camelids and their use as caravan

212 animals likely played a crucial role in the realignment of political and economic strategies during

213 the Nepeña and Samanco phases, little is currently known about the actual movements of these

214 animals and their management.

216 Huambacho and Caylán to investigate Early Horizon cultural developments in coastal Nepeña.

217 Mapping and excavation results from Caylán indicate that the Early Horizon settlement was

218 organized into more than 40 monumental house compounds agglutinated into a dense urban core

219 and articulated through a complex network of streets and alleyways. Excavations sampled more

220 than $560 \mathrm{~m}^{2}$ and yielded information on different types of primary and secondary discard

221 contexts including floor scatters, open air middens, and construction fills (Figure 4). A total of

222 six excavation areas (UE1-6), and sixteen test units (HP1-16) were excavated, along with the

223 clearing of a looter's pit (PH1). Overall, the excavated contexts and associated structures and 
224 materials allow for a preliminary consideration of (1) a monumental platform complex (Main

225 Mound Complex, UE1, 4), (2) a public space (Plaza-A, UE2, 5), (3) a multi-functional residence

226 (Compound-E, UE6), and (4) several other discard areas located throughout the site and sampled

227 through UE3, the test pits (HP), and PH1. The samples of camelid remains analyzed in this

228 article come the Main Mound Complex (n=8), Plaza-A and one of its adjacent patios $(n=6)$, the

229 residential portion of Compound-E $(n=5)$, as well as peripheral open-air middens $(n=3)$. Overall,

230 the samples from Caylán appear to correspond to discard episodes associated with the

231 ceremonial use of plaza and mound spaces (Main Mound, Plaza-A), the more domestic or daily

232 consumption of camelids (Compound-E), as well as the secondary transport of skeletal remains

233 away from the urban core. Stylistic evidence and radiocarbon measurements suggest that all the

234 sectors sampled were occupied contemporaneously.

235 Meanwhile, excavations at Huambacho sampled more than $4,500 \mathrm{~m}^{2}$ and yielded insights

236 into the occupation of a small elite center located on the southern margin of the coastal plain,

237 some $8 \mathrm{~km}$ from the shoreline. Here, materials mainly came from the clearing of plazas and patio

238 halls associated with feasting practices and ceremonial gatherings. More specifically, the camelid

239 remains analyzed in this study are associated with the use of a monumental plaza (Plaza-B, $n=1$ ),

240 as well as a small mound complex interpreted as an elite residence (Huaca-A, $\mathrm{n}=2$ ). Radiocarbon

241 measurements securely place the excavated contexts at Caylán and Huambacho within the Early

242 Horizon (Chicoine 2010a; Chicoine and Ikehara 2010, 2014).

243 The excellent organic preservation at both sites allowed the recovery of a rich faunal

244 assemblage. Taxonomic analyses of the vertebrate remains indicate that the dwellers of these two

245 Early Horizon settlements interacted with, used, ate, and processed a vast array terrestrial,

246 marine, riverine, and lacustrine vertebrates including amphibians, reptiles, fish, birds, and 
247 mammals. The role of camelids was likely diverse, serving as pack animals, sources of meat and 248 bones, and perhaps fibers. Yet, solid conclusions about local herding practices remain out of

249 reach since no corrals, dung, or other indications of in situ husbandry were detected at Caylán or

250 Huambacho. It is significant, however, that recent fieldwork at Samanco, an Early Horizon site

251 located $2 \mathrm{~km}$ from the coast on the northern margin of the lower Nepeña, revealed a series of

252 rectangular rooms with large amounts of compacted camelid dung (Helmer and Chicoine In

253 Press). With a surface area of more than $800 \mathrm{~m}^{2}$, the structure could have easily housed up to 200

254 llamas, possibly more. More research is needed on the Samanco assemblage, but it appears

255 possible that llama caravans were travelling to the coastal center to move marine resources.

256 Differences, for instance, in the composition of the shell assemblages from Samanco and Caylán

257 suggest that a limited number of select bivalve species supplied inland populations, in particular

258 the small intertidal clam Donax spp. (Chicoine and Rojas 2013). In contrast, deposits at coastal

259 settlements contain a richer and more diverse corpus (Matthew Helmer, personal communication 260 2014).

261 Nineteen camelids from Caylán and three from Huambacho were sampled for stable

262 isotope analysis (Table 1). The vast majority of the samples consisted of first phalanges, as well

263 as three astragali (although these failed to produce acceptable collagen and are not included in

264 the analysis) and a single mandible (Table 1). The same non-repetitive elements were sampled

265 from each context (i.e. Main Mound, Plaza-A, Compound-E at Caylán) to avoid sampling the

266 same individual. Based on the epiphyseal fusion data provided in Kent (1982), the animals

267 sampled were all $>2$ years of age.

269 Methods 
Because it is exceptionally difficult and in most cases impossible to accurately

271 differentiate South American camelid species on the basis of postcranial skeletal elements

272 (Shimada 1982), the samples analyzed in this study could only be identified as camelids and not

273 to any particular species. Based on limited osteometric analyses conducted on camelids

274 recovered from Early Horizon contexts, these individuals are more similar to modern llamas than

275 they are to alpacas (Vásquez and Rosales 2012).

276 Bone collagen was extracted using previously described methods (Szpak et al. 2014).

277 Isotopic and elemental compositions $\left(\delta^{13} \mathrm{C}, \delta^{15} \mathrm{~N}, \% \mathrm{C}, \% \mathrm{~N}\right)$ were determined using a Thermo

278 Finnigan Delta V continuous flow mass spectrometer coupled to a Costech Elemental Analyzer

279 at the Laboratory for Stable Isotope Science (University of Western Ontario). Carbon and

280 nitrogen isotopic compositions were calibrated to VPDB and AIR with USGS40 (glutamic acid,

281 accepted values $\delta^{13} \mathrm{C}=-26.39 \%, \delta^{15} \mathrm{~N}=-4.52 \%$ ) and USGS41 (glutamic acid, accepted

282 values $\delta^{13} \mathrm{C}=37.63 \%$, $\delta^{15} \mathrm{~N}=47.6 \%$ ). Details on analytical accuracy and precision are

283 summarized in the Supplementary Material.

284 All statistical analyses were performed with the open source statistical package $\mathrm{R}$ ( $\mathrm{R}$

285 Development Core Team 2007) for Mac OS X. Relative contributions of $\mathrm{C}_{3}$ and $\mathrm{C}_{4}$ plants were

286 quantified using a single isotope Bayesian mixing model with the SIAR package (Parnell et al.

287 2010). The following parameters were used in the mixing model:

288 Sources: $\mathrm{C}_{3}$ plants $(-26.12 \pm 1.75 \%)$ and $\mathrm{C}_{4}$ plants $(-12.01 \pm 0.95 \%)$. These values represent

289 means \pm one standard deviation of wild and cultivated plants sampled in northern Peru (Szpak et

290 al. 2012a). The values presented above have been adjusted by $+1.50 \%$ to account for the Suess

291 Effect (Yakir 2011). 
292 Corrections: Trophic level fractionation for bone collagen was obtained from a survey of

293 published literature (Szpak et al. 2012b): $\Delta{ }^{13} \mathrm{C}_{\text {collagen-diet }}=+3.6 \pm 1.7 \%$.

295 Results

296 Isotopic and elemental compositions for all specimens analyzed are presented in Table 1.

297 Nineteen of the twenty-two specimens from which collagen was extracted produced atomic C:N

298 ratios within the range of accepted values for well-preserved bone collagen (2.9-3.6) as reported

299 by DeNiro (1985). For the 19 samples with acceptable C:N ratios, collagen yields were $>1 \%$,

300 while the 3 samples with unacceptable C:N ratios were also characterized by collagen yields

$301<1 \%$ (AIS-1299, AIS-1313, AIS-1314). Accordingly, results for these three samples have been

302 omitted from all summary statistics, plots, and analyses (Ambrose 1990).

303 Individual carbon and nitrogen isotopic compositions for the Nepeña camelids are plotted

304 in Figure 5A and Figure 5B. These data are overlain atop heat plots generated on the basis of

305 isotopic datasets for camelids from coastal archaeological sites $(n=160)$ and highland

306 archaeological sites as well as modern highland ( $>3,200$ masl) camelids $(n=155)$ (compiled by

307 Szpak 2013). The majority (16/19) of the Nepeña camelids (those with $\delta^{13} \mathrm{C}$ values $<-16 \%$ ) fit

308 generally with the isotopic compositions of high altitude camelids, although three individuals

309 from Caylán (those with $\delta^{13} \mathrm{C}$ values $>-16 \%$ ) have isotopic compositions inconsistent with

310 high altitude pasturing.

311 The results of the two-source $\left(\mathrm{C}_{3} / \mathrm{C}_{4}\right)$ Bayesian mixing model (SIAR) are presented in

312 Figure 6. Two comparative camelid datasets are also presented in: a group of Middle Horizon

313 camelids from a high altitude herding site (Chinchawas in the Callejón de Huaylas) and a group

314 of Early Intermediate Period camelids from a coastal site (Huaca Gallinazo in the Virú Valley) 
315 (Szpak et al. 2014; Szpak et al. 2015). On the basis of a growing body of isotopic measurements

316 of camelids from coastal, highland, and intermediate altitudes in Peru (DeNiro 1988; Verano and

317 DeNiro 1993; Finucane et al. 2006; Thornton et al. 2011; Szpak 2013; Dufour et al. 2014; Szpak

318 et al. 2014; Szpak et al. 2015; Szpak et al. In Press), the two comparative datasets presented in

319 Figure 6 are the largest and are representative of typical coastal and highland patterns.

320 Collectively, the Caylán camelids are characterized by intermediate carbon isotopic

321 compositions relative to the comparative groups from the coast (Huaca Gallinazo) and highlands

322 (Chinchawas). These comparisons do not take into account any intragroup complexities that may

323 drive these patterns, which is somewhat problematic. The majority of the Caylán camelids have

$324 \delta^{13} \mathrm{C}$ values between -20 and $-16 \%$ and a panel is included in Figure 6 that removes the three

325 individuals with $\delta^{13} \mathrm{C}$ values greater than $-16 \%$. Even after removing these three values, the

326 Caylán camelids still have diets consistent with significantly greater $\mathrm{C}_{4}$ plant consumption than

327 the Chinchawas (highland) camelids $(p<0.001)$ suggesting some differences in camelid life

328 histories between the two groups. Therefore, neither the coastal pattern of diversified camelid

329 husbandry involving significant $\mathrm{C}_{4}$ plant foddering (Szpak et al. 2014), the specialized urban

330 pattern of almost exclusively maize foddering (Finucane et al. 2006), nor the highland pattern of

331 pasturing (as is seen in the Chinchawas data) adequately characterizes the Caylán camelids.

333 Discussion

334 We posit that the isotopic data for the Caylán camelids are reflective of two economic

335 strategies. The first involves the acquisition of camelid livestock traded in from higher altitude

336 zones. These animals were likely born in the highlands and moved to the coast at some point in

337 their lives prior to being killed and consumed. They may have been animals associated with or 
338 part of caravans that moved to and from the coast, consuming a more mixed $\mathrm{C}_{3} / \mathrm{C}_{4}$ diet than

339 those animals living exclusively on the high altitude pastures of the puna, with maize fodder

340 being provided to the animals at various points along the way, possibly in exchange for goods

341 being moved by the caravans - this practice was recorded in ethnohistoric accounts (e.g. Zárate

342 1555).

343 While we cannot definitely rule out that the camelids with relatively low $\delta^{13} \mathrm{C}$ values

344 were not foddered with local $\mathrm{C}_{3}$ forage - the practice of feeding camelids with the beans and

345 pods of the algorrobo tree (Prosopis sp., a $\mathrm{N}_{2}$-fixing $\mathrm{C}_{3}$ species common in coastal Peru) has

346 been observed in coprolites from coastal Late Intermediate Period specimens (Shimada and

347 Shimada 1985) - this explanation seems unlikely given that this pattern (at the site level) has not

348 been observed in over 200 camelid $\mathrm{C}$ and $\mathrm{N}$ isotopic measurements from 12 other coastal sites

349 (DeNiro 1988; Verano and DeNiro 1993; Szpak 2013; Szpak et al. 2014; Szpak et al. In Press).

350 Moreover, there is limited additional evidence supporting local camelid husbandry, such as the

351 presence of structures resembling corrals or the accumulation of significant quantities of dung

352 (for examples on the coast, see Shimada 1981; Wilson 1988; Szpak et al. 2014). This negative

353 evidence has to be interpreted with caution, but the fact remains that most of the animals have

$354 \delta^{13} \mathrm{C}$ values that do not accord well with intensive patterns of local husbandry, but these camelids

355 were consuming more $\mathrm{C}_{4}$ plants than would be expected for animals raised in the puna. Instead,

356 we suggest that these camelids were acquired via trade with caravans.

357 While no isotopic studies have been performed on modern or archaeological animals

358 known or suspected (in the case of the latter) to have been associated with caravans, modern

359 observations suggest that caravan animals begin training after two years of age (spending this

360 time in the puna) and consist exclusively of castrated males between 2 and 8 years of age 
361 (Nielsen 2001). In the course of their movements, caravan animals graze on locally abundant

362 forage and in some cases are provided with fodder from agricultural products or permitted

363 (sometimes encouraged) to graze field stubble, which typically includes maize at altitudes below

3643,500 masl (Browman 1990b).

365 In southern Peru, modern llama herders often arranged trading trips to the coast at the end

366 of the maize harvest, where animals could have grazed maize stubble intensively, but for a short

367 period of time (Browman 1990a). Thus, animals acquired as adults that were part of caravans

368 would likely show a predominantly $\mathrm{C}_{3}$ diet, particularly if bone remodeling rates are such that

369 the isotopic signature of the collagen disproportionately represents periods of accelerated bone

370 growth early in life (Hedges et al. 2007), when the animals were still living in the puna.

371 Interestingly, there is a strong positive correlation between $\delta^{13} \mathrm{C}$ and $\delta^{15} \mathrm{~N}$ values for the Nepeña

372 camelids consuming predominantly $\mathrm{C}_{3}$ plants (Spearman's $\rho=0.76, \mathrm{p}<0.001$ ), suggesting that the

$373 \mathrm{C}_{4}$ plants consumed by these camelids had significantly higher $\delta^{15} \mathrm{~N}$ values than the $\mathrm{C}_{3}$ plants

374 they consumed.

375 By way of comparison, the camelids from the high altitude herding site of Chinchawas

376 (Szpak et al. 2015) show a negative, but not statistically significant correlation between bone

377 collagen $\delta^{13} \mathrm{C}$ and $\delta^{15} \mathrm{~N}$ values (Spearman's $\rho=-0.50, \mathrm{p}=0.08$ ). These animals are believed to

378 have been alpacas (Lau 2007), and hence would not have been caravan animals moving between

379 altitudinal zones. There are two plausible scenarios for the correlation observed for the Caylán

380 camelids, both of which fit with the consumption of maize from field stubble. They are,

381 however, not mutually exclusive. First, if camelids regularly visited maize plots, they may have

382 deposited significant quantities of dung as they grazed; recent accounts report this activity for

383 modern camelids in agricultural fields after the harvest (McCorkle 1987; Mitchell 1991; Goland 
384 1993). Indeed, Orlove (1977a) points out the importance of the addition of highland camelid

385 dung for lowland crop growth. The addition of camelid dung to maize fields significantly

386 increases plant tissue $\delta^{15} \mathrm{~N}$ values by between 2 and $4 \%$, even after a single season and at a

387 relatively low rate of application (Szpak et al. 2012a). If caravan camelids consumed this

388 fertilized maize, it would fit with the positive correlation between $\delta^{13} \mathrm{C}$ and $\delta^{15} \mathrm{~N}$ values observed

389 here for Caylán camelid bone collagen. An additional consideration is the type of plant tissue

390 consumed.

391 The fact that animals are only permitted to graze on the leaves and stalks in maize fields

392 is significant because there is consistent intraplant $\delta^{15} \mathrm{~N}$ variation in annual crops such as maize.

393 Specifically, leaves and stems have consistently higher $\delta^{15} \mathrm{~N}$ values than grains because of

394 reallocation and resultant discrimination against ${ }^{15} \mathrm{~N}$ that occurs during grain filling; these

395 differences may be on the order of several per mil, and significantly higher $(>5 \%)$ under

396 conditions of high nitrogen availability, such as occurs with fertilization (Szpak 2014).

397 Therefore, we would expect animals that had diets consistent with this pattern of seasonal, but

398 relatively limited, fertilized maize leaf and stem consumption to be characterized by carbon and

399 nitrogen isotopic compositions observed for the majority of the Early Horizon camelids.

$400 \quad$ Although marine fauna are both abundant and diverse at Caylán and Huambacho

401 (Chicoine and Rojas 2012, 2013), camelids are the most abundant vertebrate taxon. At Caylán,

402 they represent $13.3 \%$ of the total NISP $(n=3,289)$, and $37.4 \%$ of the NISP for mammals

$403(\mathrm{n}=1,661)$. Similarly, at Huambacho, camelids comprise $39.8 \%$ of the vertebrate NISP

$404(\mathrm{n}=1,300)$. That most of the camelid remains analyzed have isotopic compositions consistent

405 with a non-local origin suggests that the local population may have relied to a large extent on 
406 imported camelid meat, which implies a significant level of interaction between coastal and

407 highland communities during the Early Horizon.

408 During the 1st millennium BC, many transformations can be evoked to account for

409 increased contacts between coastal and highland communities. Technological advances were

410 made, either through innovation or improvement of Initial Period traditions (Burger 1988;

411 Kembel and Rick 2004), however, it is the development of Chavín de Huantar and the spread of

412 the Chavín cult that have traditionally been seen as the main driving forces of change (Keatinge

413 1981). The Chavín cult was materialized in an iconography centered on images of felines,

414 raptorial birds, caimans, and San Pedro cactus, and expressed the predominance of shamanistic

415 beliefs. It is believed that ideological and religious ties were materialized in similar ritual

416 paraphernalia, iconography, and ceremonial architecture (Burger 1992). In contrast to day-to-day

417 interactions, these interregional interactions existed within the realm of elites.

418 Some scholars have emphasized the more socioeconomic and political aspects of

419 interregional networks, outlining the limitations of considering the Chavín influence as solely

420 religious (Burger and Matos 2002). They suggest that the circulation of valuables, from the

421 extraction of special materials to the crafting of fine artifacts and the acquisition of non-local

422 goods, primarily answered economic and sociopolitical concerns. From this perspective, groups

423 with privileged access to prized resources and valuables would take advantage of the situation to

424 position themselves within regional networks and increase their power and influence. Burger and

425 Matos (2002) provide an example from the Early Horizon site of Atalla in the central highlands

426 and suggest that the local availability of cinnabar, a mineral valued for its bright red color and

427 used during the Early Horizon in burial rites and for decorating ceremonial objects and buildings,

428 allowed local leaders to gain power. These interactions would have materialized in the 
429 identification of Atalla elites to Chavín precepts and materialized in the emulation of Chavín

430 ceramic styles (Burger and Matos 2002).

431 In coastal Nepeña, recent research has questioned traditional connections with the Chavín

432 phenomenon and the adjacent highlands (Chicoine 2006, 2010b; Shibata 2010, 2011); especially

433 considering the reevaluation of the occupational history and chronology at Chavín de Huantar

434 (Burger and Salazar-Burger 2008; Rick et al. 2011). While Chavín-related and Cupisnique

435 stylistic features are evident at the late Initial Period ceremonial centers of Cerro Blanco and

436 Huaca Partida, by the time of the emergence of urban communities at Caylán and associated

437 settlements, coastal populations appear to have steered clear of Chavín imagery. Yet, it is

438 precisely during this transition that camelids begin to be common in coastal Ancash. This is

439 likely related to the intensification of bulk exchanges, likely of subsistence goods, along the

440 coast, but perhaps more importantly - based on the results of our isotope study in Nepeña -

441 between the coast and the adjacent highland regions. This suggests that coast-highland

442 interaction networks survived the demise of Chavín-related phenomena, although these were

443 likely substantially reorganized. Here, llama caravans appear to have been important in the

444 transportation of goods between Early Horizon coastal populations and settlements in the more

445 elevated highland regions, likely the Callejón de Huaylas. It is unclear at the moment if these

446 extra-local interaction networks channeled exotic and prestige items, and/or more mundane

447 subsistence staples, but the presence of a camelid corral at the Early Horizon fishing community

448 of Samanco suggests that dried fish and other marine resources were being moved across

449 Ancash. The presence of large amounts of select shell species at inland communities strengthens

450 this assertion (Chicoine and Rojas 2012, 2013). 
As mentioned previously, the three Caylán camelids with $\delta^{13} \mathrm{C}$ values higher than $-15 \%$

452 do not fit with the highland mode of pastoralism. Therefore, these individuals merit some

453 additional discussion. There are three reasonable possibilities that might explain the Caylán

454 camelids with relatively high $\delta^{13} \mathrm{C}$ values. First, the local populace was beginning to experiment

455 with camelid herding some time during the Early Horizon and supplied these animals with

456 fodder that included significant quantities of $\mathrm{C}_{4}$ plants, most likely maize byproducts, but wild

457 local $\mathrm{C}_{4}$ grass species (e.g., Distichlis sp.) may have formed an important part of the diet

458 (Shimada and Shimada 1985). An additional source of wild forage with high $\delta^{13} \mathrm{C}$ values may

459 have been lomas (fog oases) located in the Andean foothills. These ephemeral formations occur

460 sporadically throughout the Andes (Ono 1986) and today exist in relatively close proximity to

461 both Caylán and Huambacho in the coastal portion of the Nepeña Valley. Thornton et al. (2011)

462 interpret several individual camelids from Cerro Baúl with relatively high $\delta^{13} \mathrm{C}$ and $\delta^{15} \mathrm{~N}$ values

463 as possibly having grazed in lomas environments.

464 Second, these camelids may also have been caravan animals that for some reason

465 happened to have consumed significantly higher quantities of $\mathrm{C}_{4}$ plants than the other individuals

466 despite occupying a similar economic role. Given the limited availability of $\mathrm{C}_{4}$ plants throughout

467 most of the year at high altitudes, however, this seems unlikely. A more plausible scenario is that

468 these animals were foddered in a way that was distinct from the majority of the Early Horizon

469 coastal camelids because they spent a significant portion of their lives in another location.

$470 \quad$ It is possible that the Caylán camelids with relatively high $\delta^{13} \mathrm{C}$ values may have

471 originated outside of the puna pastures above 3,500 masl, but were raised in the intermediate low

472 or high sierra zones (c. 2,300 to 3,500 masl) where maize cultivation still occurs. The high $\delta^{13} \mathrm{C}$

473 values recorded for the camelids from the Middle Horizon (c. AD 550 to 1000) occupation at 
474 Conchopata, which is located at c. 2,700 masl demonstrate the possibility of camelids being

475 foddered on large amounts of $\mathrm{C}_{4}$ plants (Finucane et al. 2006), although this is the only instance

476 in which such a pattern has been observed and relevant data are lacking from earlier periods. The

$477 \mathrm{C}_{3}$ consuming animals at Conchopata have been interpreted to be alpacas that grazed not locally,

478 but in the puna, and the $\mathrm{C}_{4}$ consuming animals were likely corralled and foddered with maize

479 and/or allowed to graze maize stubble in local agricultural fields (Finucane et al. 2006). This

480 latter pattern of camelid husbandry is very similar to what has been suggested for the north coast

481 during the EIP and Middle Horizon (Dufour et al. 2014; Szpak et al. 2014; Szpak et al. In Press).

482 In other words, while foddering camelids with significant quantities of maize is possible at

483 intermediate altitudes, there is no basis to suggest that it would be any more likely than at low

484 altitudes. There is evidence for corralling and the presence of maize in camelid dung at nearby

485 Samanco in the Nepeña Valley, suggesting local herding of camelids at this site, although the

486 broader regional importance and temporal scale of this activity is presently unclear. That there is

487 some evidence of local corrals and the fact that these animals have isotopic compositions

488 completely inconsistent with high altitude herding (Figure 5A), similarly do not fit with the other

489 Caylán camelids that we have interpreted to be caravan animals. This leads us to hypothesize that

490 people in the lower Nepeña Valley were experimenting with local camelid herding during the

491 Early Horizon. The isotope results suggest dynamic human-animal relationships at the onset of

492 the Early Horizon in which camelids were gradually being brought to and eventually corralled

493 and raised on the coast. This is particularly significant in the context of incipient urban

494 settlements, such as Caylán, where many human groups had the potential to become specialized

495 and detached from primary subsistence activities. Indeed, urban dwellers can acquire meat and

496 other animal products directly or indirectly through state-sponsored and other centralized 
497 systems (Zeder 1991). Traditionally, archaeologists have hypothesized that the development of

498 state-like and other stratified societies led to increasingly efficient and centralized systems of

499 animal management (i.e., increasing number of non-food producers are provisioned by

500 centralized economic/redistributive mechanisms/institutions). In coastal Ancash, it appears that

501 the introduction and increased reliance on camelids as beasts of burdens played a major role in

502 the development of long-distance trade and its associated routes and networks.

503 That the isotopic data for the Caylán camelids are quite distinct from other coastal sites

504 where husbandry appears much more established (Dufour et al. 2014; Szpak et al. 2014; Szpak

505 et al. In Press) suggests that the activity of local raising camelids was not of great economic

506 importance in Nepeña during the Early Horizon. Herd sizes collectively throughout the valley

507 may have not have been large enough to sustain a local population and the addition of new

508 animals was likely primarily through the acquisition of young animals from highland herds.

509 Shimada and Shimada (1985) posited that llamas were successfully bred and maintained on the

510 north coast of Peru from at least the Middle Horizon (c. AD 600) and possibly dating back to the

511 Early Horizon (c. 200 BC). The results presented here suggest that the experimentation with

512 coastal camelid husbandry through the occasional acquisition of caravan llamas may have begun

513 during the Early Horizon, at least in Ancash, but this hypothesis requires testing through the

514 collection of additional data from other sites, both in Nepeña and along the entire coast, that

515 predate the EIP.

516

517 Conclusions

518 The principal source for camelid consumption at Caylán and Huambacho appears to have

519 been the acquisition of llamas that were likely part of caravans moving between the coast and the 
520 highlands. These animals consumed significant quantities of maize, likely stems and leaves and

521 probably fertilized maize plots as they grazed, but for relatively short periods of the year. A

522 small number of camelids from Caylán have isotopic compositions consistent with being raised

523 locally on the coast, suggesting that the local populace in Nepeña may have been experimenting

524 with this activity during the Early Horizon. Although the data for Caylan is the third largest

525 sample of camelids from a single site in Peru produced to date, additional data from

526 contemporaneous sites are necessary before any clear picture of animal management during the

527 Early Horizon can develop.

528

529

530

531 


\section{Acknowledgements}

533 Kim Law and Li Huang provided technical assistance. This project was supported by the Wenner

534 Gren Foundation (Dissertation Fieldwork Grant to PS), Social Sciences and Humanities

535 Research Council of Canada (Standard Research Grant to CDW, FJL, JFM; Bombardier

536 Doctoral CGS to PS), Natural Sciences and Engineering Research Council Discovery Grant

537 (FJL), Canada Foundation for Innovation and Ontario Research Fund Infrastructure grants (FJL),

538 Canada Research Chairs Program (CDW, FJL), and The University of Western Ontario. Isotopic

539 research was conducted under Resolutción Vicesministerial No. 014-2013-VMPCIC-MC.

540 Excavations at Caylán were realized with the kind permission and supervision of the Instituto

541 Nacional Cultura (permits 804/INC-050609, 1230/INC-280510). Author Contributions: PS, DC,

542 CDW, JFM, FJL designed research. PS and RP performed research. PS, DC, CDW, JFM, FJL

543 interpreted the data. PS and DC wrote the paper with editorial input from FJL, CDW, JFM, RP.

544 This is Laboratory for Stable Isotope Science Contribution \#323.

545

546 
Aldenderfer, M. 2001. Andean Pastoral Origins and Evolution: The Role of Ethnoarchaeology, pp. 19-30 in Kuznar, L.A. (ed.) Ethnoarchaeology of Andean South America: Contributions to Archaeological Method and Theory, Ann Arbor: International Monographs in Prehistory. Ethnoarchaeological Series 4.

552

553

554

Aldenderfer, M. 2006. Costly signaling, the sexual division of labor, and animal domestication in the Andean highlands, pp. 167-196 in Kennett, D.J., Winterhalder, B. (eds.), Behavioral Ecology and the Transition to Agriculture, Berkeley: University of California Press.

Ambrose, S.H. 1990. Preparation and characterization of bone and tooth collagen for isotopic analysis. Journal of Archaeological Science 17: 431-451.

Amundson, R., Austin, A.T., Schuur, E.A.G., Yoo, K., Matzek, V., Kendall, C., Uebersax, A., Brenner, D., Baisden, W.T. 2003. Global patterns of the isotopic composition of soil and plant nitrogen. Global Biogeochemical Cycles 17: 1031.

Baied, C.A., Wheeler, J.C. 1993. Evolution of High Andean Puna Ecosystems: Environment, Climate, and Culture Change over the Last 12,000 Years in the Central Andes. Mountain

Beaule, C. 2012. Wealth on the hoof: Camelid faunal remains and subsistence practices in

Bonavia, D. 2008. The South American Camelids. Los Angeles: Cotsen Institute of Archaeology,

Boytner, R. 2004. Clothing the social world, pp. 130-145 in Silverman, H. (ed.) Andean Archaeology, Malden, MA: Blackwell.

569 Browman, D.L. 1974. Pastoral nomadism in the Andes. Current Anthropology 15: 188-196.

570 Browman, D.L. 1975. Trade Patterns in the Central Highlands of Peru in the First Millennium B.C. World Archaeology 6: 322-329.

Browman, D.L. 1984. Tiwanaku: Development of Interzonal Trade and Economic Expansion in the Altiplano, pp. 117-131 in Browman, D.L., Burger, R.L., Rivera, M.A. (eds.), Social and Economic Organization in the Prehispanic Andes, Oxford: BAR International Series 194.

Browman, D.L. 1989. Origins and development of Andean pastoralism: an overview of the past 6000 years, pp. 256-268 in Clutton-Brock, J. (ed.) The Walking Larder: Patterns of Domestication, Pastoralism, and Predation, London: Unwin Hyman.

Browman, D.L. 1990a. Camelid pastoralism in the Andes: Llama caravan fleteros, and their importance in production and distribution, pp. 395-438 in Salzman, P.C., Galaty, J.G. (eds.), Nomads in a Changing World, Naples: Instituto Universitario Orientale. 
581 Browman, D.L. 1990b. High altitude camelid pastoralism of the Andes, pp. 323-352 in Galaty, J.G., Johnson, D.L. (eds.), The World of Pastoralism: Herding Systems in Comparative Perspective, New York: The Guilford Press.

584 Bruno, M.C. 2014. Beyond Raised Fields: Exploring Farming Practices and Processes of Agricultural Change in the Ancient Lake Titicaca Basin of the Andes. American Anthropologist 116: 130-145.

587 Bryant, F.C., Farfan, R.D. 1984. Dry Season Forage Selection by Alpaca [Lama pacos] in 588

Burger, R.L. 1988. Unity and Heterogeneity within the Chavín Horizon, pp. 99-144 in Keatinge,

Burger, R.L. 1992. Chavin and the Origins of Andean Civilization. New York: Thames \& R.W. (ed.) Peruvian Prehistory: An Overview of Pre-Inca and Inca Society, Cambridge: Cambridge University Press.

594 Burger, R.L., Matos, R.M. 2002. Atalla: a center on the periphery of the Chavin horizon. Latin American Antiquity 13: 153-177.

Burger, R.L., Salazar-Burger, L. 2008. The Manchay Culture and the Coastal Inspiration for Highland Chavín Civilization, pp. 85-105 in Conklin, W.J., Quilter, J. (eds.), Chavin: Art, Architecture, and Culture, Los Angeles: Cotsen Institute of Archaeology Press.

599 Chapdelaine, C. 2011. Recent Advances in Moche Archaeology. Journal of Archaeological $600 \quad$ Research 19: 191-231.

601 Chicoine, D. 2006. Early Horizon Architecture at Huambacho, Nepeña Valley, Peru. Journal of 602 Field Archaeology 31: 1-22.

603 Chicoine, D. 2010a. Cronología y secuencias en Huambacho, valle de Nepeña, costa de Ancash. 604 Boletín de Arqueología PUCP 12: 317-348.

605 Chicoine, D. 2010b. Elite Strategies and Ritual Settings in Coastal Peru during the 1st Millenium

609 Chicoine, D. 2011. Feasting landscapes and political economy at the Early Horizon center of 610 Huambacho, Nepena Valley, Peru. Journal of Anthropological Archaeology 30: 432-453.

611 Chicoine, D., Ikehara, H. 2010. Nuevas evidencias sobre el Periodo Formativo del valle de 612 Nepeña: Resultados preliminares de la primera temporada de investigaciones en Caylán. 613 Boletín de Arqueología PUCP 12: 349-370. 
614 Chicoine, D., Rojas, C. 2012. Marine Exploitation and Paleoenvironment as Viewed through 615 Molluscan Resources at the Early Horizon Center of Huambacho, Nepeña Valley, Peru. 616 Andean Past 10: 284-290.

617 Chicoine, D., Rojas, C. 2013. Shellfish Resources and Maritime Economy at Caylán, Coastal 618 Ancash, Peru. The Journal of Island and Coastal Archaeology 8: 336-360.

619 Chicoine, D., Ikehara, H. 2014. Ancient urban life at the Early Horizon center of Caylán, Peru. $620 \quad$ Journal of Field Archaeology 39: 336-352.

621 Chicoine, D., Clement, B., Stich, K. In Press. Macrobotanical Remains from the 2009 Season at Caylán: Preliminary Insights into Early Horizon Plant Use in the Nepeña Valley, NorthCentral Coast of Peru. Andean Past 12.

624 Cotrina, J., Peña, V., Tandaypan, A., Pretell, E. 2013. Evidencias Salinar: sitios VN-35 y VN-36, 625 Sector Sute Bajo, valle de Nepeña. Revista Arqueológica SIAN 14: 7-12.

Craine, J.M., Elmore, A.J., Aidar, M.P.M., Bustamante, M., Dawson, T.E., Hobbie, E.A., Kahmen, A., Mack, M.C., McLauchlan, K.K., Michelsen, A., Nardoto, G.B., Pardo, L.H., Peñuelas, J., Reich, P.B., Schuur, E.A.G., Stock, W.D., Templer, P.H., Virginia, R.A., Welker, J.M., Wright, I.J. 2009. Global patterns of foliar nitrogen isotopes and their relationships with climate, mycorrhizal fungi, foliar nutrient concentrations, and nitrogen availability. New Phytologist 183: 980-992.

Daggett, R.E. 1983. The Early Horizon-Early Intermediate Period transition: a view from the Nepaña and Virù Valleys, pp. 41-66 in Kvietok, D.P., Sandweiss, D.H. (eds.), Recent Studies in Andean Prehistory and Protohistory. Papers from the Second Annual Northeast Conference on Andean Archaeology and Ethnohistory, Ithaca: Cornell University, Latin American Studies Program.

Daggett, R.E. 1984. The Early Horizon Occupation of the Nepeña Valley, North Central Coast of Peru. Unpublished Ph.D. Dissertation, University of Massachusetts.

deFrance, S.D. 2010. Paleopathology and health of native and introduced animals on Southern Peruvian and Bolivian Spanish Colonial sites. International Journal of Osteoarchaeology 20: 508-524.

DeNiro, M.J. 1985. Postmortem preservation and alteration of in vivo bone collagen isotope ratios in relation to palaeodietary reconstruction. Nature 317: 806-809.

DeNiro, M.J. 1988. Marine food sources for prehistoric coastal Peruvian camelids: isotopic evidence and implications. British Archaeological Reports, International Series 427, pp. 119128 in Wing, E.S., Wheeler, J.C. (eds.), Economic Prehistory of the Central Andes, Oxford: Archaeopress.

648 Donnan, C.B., Foote, L.J. 1978. Appendix 2: Child and Llama Burials from Huanchaco, pp. 399408 in Donnan, C.B., Mackey, C.J. (eds.), Ancient Burial Patterns of the Moche Valley, Peru, Austin: University of Texas Press. 
651 Dufour, E., Goepfert, N., Gutiérrez Léon, B., Chauchat, C., Franco Jordan, R., Vásquez Sánchez, 652 S. 2014. Pastoralism in northern Peru during pre-Hispanic times: insights from the Mochica Period (100-800 AD) based on stable isotopic analysis of domestic camelids. PLoS One 9: e87559.

Duncan, N.A. 2003. At the edge of the Puna: Archaeological test excavation and sampling for phytolith signatures of ancient corrals at Antibal, Peru. Unpublished M.A. Thesis, University of Missouri.

Finucane, B., Agurto, P.M., Isbell, W.H. 2006. Human and animal diet at Conchopata, Peru: stable isotope evidence for maize agriculture and animal management practices during the Middle Horizon. Journal of Archaeological Science 33: 1766-1776.

661 Flannery, K.V., Marcus, J., Reynolds, R.G. 1989. The Flocks of Wamani: A Study of the Llama

Flores-Ochoa, J.A. 1979. Pastoralists of the Andes: The Alpaca Herders of Paratia. Philadelphia: Institute for the Study of Human Issues.

Fogel, H.P. 1993. Settlements in time: A study of social and political development during the Gallinazo occupation of the north coast of Perú. Unpublished Ph.D. Dissertation, Yale University.

Gade, D.W. 1992. Landscape, System, and Identity in the Post-Conquest Andes. Annals of the Association of American Geographers 82: 460-477.

Gilmore, R.M. 1950. Fauna and Ethnozoology of South America, pp. 345-464 in Steward, J. (ed.) Handbook of South American Indians, Volume 6, Washington, D.C.: Smithsonian Institution Bureau of American Ethnology Bulletin 143.

673 Goepfert, N. 2012. New zooarchaeological and funerary perspectives on Mochica culture (A.D. 674 100-800), Peru. Journal of Field Archaeology 37: 104-120.

Goland, C. 1993. Field Scattering as Agricultural Risk Management: A Case Study from Cuyo Cuyo, Department of Puno, Peru. Mountain Research and Development 13: 317-338.

677 Grossman, J.W. 1983. Demographic change and economic transformation in the south-central highlands of pre-Huari Peru. Nawpa Pacha 21: 45-126.

Handley, L.L., Austin, A.T., Stewart, G.R., Robinson, D., Scrimgeour, C.M., Raven, J.A., Heaton, T.H.E., Schmidt, S. 1999. The ${ }^{15} \mathrm{~N}$ natural abundance $\left(\delta^{15} \mathrm{~N}\right)$ of ecosystem samples reflects measures of water availability. Australian Journal of Plant Physiology 26: 185-199.

684

Hedges, R.E.M., Clement, J.G., Thomas, D.L., O'Connell, T.C. 2007. Collagen turnover in the adult femoral mid-shaft: Modeled from anthropogenic radiocarbon tracer measurements. American Journal of Physical Anthropology 133: 808-816. 
Helmer, M., Chicoine, D. In Press. Seaside Life in Early Horizon Peru: Preliminary Insights from Samanco, Nepeña Valley. Journal of Field Archaeology.

Ikehara, H., Paipay, J.F., Shibata, K. 2013. Feasting with Zea mays in the Middle and Late Formative North Coast of Peru. Latin American Antiquity 24: 217-231.

Jackson, A.L., Inger, R., Parnell, A.C., Bearhop, S. 2011. Comparing isotopic niche widths among and within communities: SIBER - Stable Isotope Bayesian Ellipses in R. Journal of 691 Animal Ecology 80: 595-602.

692 Keatinge, R.W. 1981. The Nature and Role of Religious Diffusion in the Early Stages of State Formation: An Example from Peruvian Prehistory, pp. 172-187 in Jones, G.D., Kautz, R.R. (eds.), The Transition to Statehood in the New World, Cambridge: Cambridge University Press.

Kembel, S.R., Rick, J.W. 2004. Building Authority at Chavín de Huántar: Model of Social Organization and Development in the Initial Period and the Early Horizon, pp. Andean Archaeology, Oxford: Blackwell.

Kent, J.D. 1982. The Domestication and Exploitation of the South American Camelids: Methods of Analysis and their Application to Circum-lacustrine Archaeological Sites in Bolivia and Peru. Unpublished Ph.D. Thesis, Washington University in St. Louis.

Knudson, K.J., Gardella, K.R., Yaeger, J. 2012. Provisioning Inka feasts at Tiwanaku, Bolivia: the geographic origins of camelids in the Pumapunku complex. Journal of Archaeological Science 39: 479-491.

Kuznar, L. 1991. Herd composition in an Aymara community of the Peruvian Altiplano: A linear programming problem. Human Ecology 19: 369-387.

Kuznar, L.A. 1989. The domestication of South American camelids: Models and evidence, pp. 167-182 in Rice, D., Stanish, C. (eds.), Ecology, Settlement and History in the Osmore Drainage, Peru, Oxford: BAR International Series 545.

Lau, G.F. 2007. Animal resources and Recuay cultural transformations at Chinchawas (Ancash, Peru). Andean Past 8: 449-476.

Marcus, J., Sommer, J.D., Glew, C.P. 1999. Fish and mammals in the economy of an ancient Peruvian kingdom. Proceedings of the National Academy of Sciences of the United States of America 96: 6564-6570.

McCorkle, C.M. 1987. Punas, pastures and fields: Grazing strategies and the agropastoral dialectic in an indigenous Andean community, pp. 57-80 in Browman, D.L. (ed.) Arid Land Use Strategies and Risk Management in the Andes: A Regional Anthropological Perspective, Boulder: Westview Press.

Millaire, J.-F. 2002. Moche Burial Patterns: An Investigation into Prehispanic Social Structure. Oxford: BAR International Series 1066. 
Millaire, J.-F. 2008. Moche textile production on the Peruvian north coast: a contextual analysis, pp. 229-245 in Bourget, S., Jones, K.L. (eds.), The Art and Archaeology of the Moche: An Ancient Andean Society of the Peruvian North Coast, Austin: University of Texas Press.

Millaire, J.-F. 2010. Primary State Formation in the Virú Valley, North Coast of Peru. Proceedings of the National Academy of Sciences 107: 6186-6191.

Millaire, J.-F. 2015. The sacred character of ruins on the Peruvian north coast, pp. 50-75 in Shimada, I., Fitzsimmons, J.L. (eds.), Living with the Dead in the Andes, Tuscon: University of Arizona Press.

Miller, G.R., Burger, R.L. 1995. Our Father the Cayman, Our Dinner the Llama: Animal Utilization at Chavín de Huántar, Peru. American Antiquity 60: 421-458.

Mitchell, W.P. 1991. Peasants on the Edge: Crop, Cult, and Crisis in the Andes. Austin: University of Texas Press.

Moore, K.M. 1988. Hunting and herding economies on the Junin puna, pp. 154-166 in Wing, E.S., Wheeler, J.C. (eds.), Economic Prehistory of the Central Andes, Oxford: BAR International Series 427.

Moore, K.M. 1989. Hunting and the origins of herding in Peru. Unpublished Ph.D. Dissertation, University of Michigan.

Moore, K.M., Steadman, D.W., deFrance, S.D. 1999. Herd, fish, and fowl in the domestic and ritual economy of formative Chiripa, pp. 105-117 in Hastorf, C.A. (ed.) Early Settlement at Chiripa, Bolivia: Research of the Taraco Archaeological Project, Berkeley: Contributions No. 57, University of California.

Murra, J.V. 1962. Cloth and Its Functions in the Inca State. American Anthropologist 64: 710728.

Murra, J.V. 1965. Herds and herders in the Inca state, pp. 185-215 in Leeds, A., Vayda, A.P. (eds.), Man, Culture, and Animals: The Role of Animals in Human Ecological Adjustments, Washington, D.C.: American Association for the Advancement of Science.

Murra, J.V. 1968. An Aymara Kingdom in 1567. Ethnohistory 15: 115-151.

Murra, J.V. 1980. The Economic Organization of the Inka State. Greenwich: JAI Press.

Nielsen, A.M. 2001. Ethnoarchaeological Perspectives on Caravan Trade in the South-Central Andes, pp. 163-201 in Kuznar, L.A. (ed.) Ethnoarchaeology of Andean South America: Contributions to Archaeological Method and Theory, Ann Arbor: International Monographs in Prehistory. Ethnoarchaeological Series 4.

Ono, M. (ed.) 1986. Taxonomic and Ecological Studies on the Lomas Vegetation in the Pacific Coast of Peru. Tokyo: Makino Herbarium, Tokyo Metropolitan University. 
755 Orlove, B.S. 1977a. Integration Through Production: The Use of Zonation in Espinar. American 756 Ethnologist 4: 84-101.

757

758

759

760

761

762

763

764

765

766

767

768

769

770

771

772

773

774

775

776

777

778

779

780

781

782

783

784

785

786

Orlove, B.S. 1977b. Alpacas, Sheep, and Men: The Wool Export Economy and Regional Society of Southern Peru. New York: Academic Press.

Orlove, B.S. 1982. Native Andean Pastoralists: Traditional Adaptations and Recent Changes, pp. 95-136 in Saltzman, P.C. (ed.) Contemporary Nomadic and Pastoral Peoples: Africa and Latin America, Williamsburg: Studies in Third World Societies Publication No. 17.

Orlove, B.S., Godoy, R.A. 1986. Sectoral fallowing systems in the Central Andes. Journal of Ethnobiology 6: 169-204.

Parnell, A.C., Inger, R., Bearhop, S., Jackson, A.L. 2010. Source Partitioning Using Stable Isotopes: Coping with Too Much Variation. PLoS One 5: e9672.

Pozorski, S.G. 1979a. Late prehistoric llama remains from the Moche Valley, Peru. Annals of the Carnegie Museum 48: 139-170.

Pozorski, S.G. 1979b. Prehistoric Diet and Subsistence of the Moche Valley, Peru. World Archaeology 11: 163-184.

Proulx, D.A. 1982. Territoriality in the Early Intermediate Period: The Case of Moche and Recuay. Nawpa Pacha 20: 83-96.

R Development Core Team. 2007. R: A Language and Environment for Statistical Computing, Series R: A Language and Environment for Statistical Computing Document Institution: City.

Rauh, W. 1985. The Peruvian-Chilean deserts, pp. 239-267 in Evenari, M., Noy-Meir, I., Goodall, D.W. (eds.), Ecosystems of the World, Volume 12A: Hot Deserts and Arid Shrublands, Amsterdam: Elsevier.

Reiner, R.J., Bryant, F.C. 1986. Botanical Composition and Nutritional Quality of Alpaca Diets in Two Andean Rangeland Communities. Journal of Range Management 39: 424-427.

Reitz, E.J. 1979. Faunal materials from Viru 434: An Early Intermediate Period site from coastal Peru. Florida Journal of Anthropology 4: 76-92.

Rick, J.W., Mesía, C., Contreras, D.A., Kembel, S.R., Rick, R.M., Sayre, M.P., Wolf, J. 2011. La cronología de Chavín de Huántar y sus implicancias para el Periodo Formativo. Boletín de Arqueología PUCP 13: 87-132.

Rundel, P.W., Dillon, M.O., Palma, B., Mooney, H.A., Gulmon, S.L. 1991. The phytogeography and ecology of the coastal Atacama and Peruvian deserts. Aliso 13: 1-49. 
Sandweiss, D.H., Richardson, J.B., III. 2008. Central Andean environments, pp. 93-104 in Silverman, H., Isbell, W.H. (eds.), Handbook of South American Archaeology, New York: Springer.

Schoeninger, M.J., DeNiro, M.J. 1984. Nitrogen and carbon isotopic composition of bone collagen from marine and terrestrial animals. Geochimica et Cosmochimica Acta 48: 625639 .

Shibata, K. 2010. Cerro Blanco de Nepeña dentro de la dinámica interactiva del Periodo Formativo. Boletín de Arqueología PUCP 12: 287-315.

795

796

797

798

799

800

801

802

803

804

805

806

807

808

809

810

811

812

813

814

815

816

817

818

819

820

Shibata, K. 2011. Cronología, relaciones interregionales y organización social en el Formativo: esencia y perspectiva del valle bajo de Nepeña, pp. 113-134 in Giersz, M., Ghezzi, I. (eds.), Arqueologia de la Costa de Ancash, Warsaw/Lima: Centro de Estudios Precolombinos de la Universidad de Varsovia/Institut Français d'Études Andines.

Shimada, I. 1981. The Batan Grande-La Leche Archaeological Project: the First Two Seasons. Journal of Field Archaeology 8: 405-446.

Shimada, M. 1982. Zooarchaeology of Huacaloma: Behavioral and Cultural Implications, pp. 303-336 in Terada, K., Onuki, Y. (eds.), Excavations at Huacaloma in the Cajamarca Valley, Peru, 1979, Tokyo: University of Tokyo Press.

Shimada, M., Shimada, I. 1985. Prehistoric llama breeding and herding on the north coast of Peru. American Antiquity 50: 3-26.

Stahl, P.W. 1988. Prehistoric camelids in the lowlands of Western Ecuador. Journal of Archaeological Science 15: 355-365.

Stenhouse, M.J., Baxter, M.S. 1979. The uptake of bomb ${ }^{14} \mathrm{C}$ in humans, pp. 324-341 in Berger, R., Suess, H.E. (eds.), Radiocarbon dating, Berkeley: University of California Press.

Stone-Miller, R. 1992. Camelids and chaos in Huari and Tiwanaku textiles, pp. 334-345 in Townsend, R.F. (ed.) The Ancient Americas: Art from Sacred Landscapes, Munich: Prestel Verlag and the Art Institute of Chicago.

Szpak, P. 2013. Stable Isotope Ecology and Human-Animal Interactions in Northern Peru. Unpublished Ph.D. Dissertation, The University of Western Ontario.

Szpak, P. 2014. Complexities of Nitrogen Isotope Biogeochemistry in Plant-Soil Systems: Implications for the Study of Ancient Agricultural and Animal Management Practices. Frontiers in Plant Science 5: 288.

Szpak, P., Millaire, J.-F., White, C.D., Longstaffe, F.J. 2012a. Influence of seabird guano and camelid dung fertilization on the nitrogen isotopic composition of field-grown maize (Zea mays). Journal of Archaeological Science 39: 3721-3740. 
821 Szpak, P., Orchard, T.J., McKechnie, I., Gröcke, D.R. 2012b. Historical ecology of late 822 Holocene sea otters (Enhydra lutris) from northern British Columbia: isotopic and zooarchaeological perspectives. Journal of Archaeological Science 39: 1553-1571.

824 Szpak, P., Millaire, J.-F., White, C.D., Longstaffe, F.J. 2014. Small scale camelid husbandry on the north coast of Peru (Virú Valley): Insight from stable isotope analysis. Journal of Anthropological Archaeology 36: 110-129.

Szpak, P., White, C.D., Longstaffe, F.J., Millaire, J.-F., Vásquez Sánchez, V.F. 2013. Carbon and Nitrogen Isotopic Survey of Northern Peruvian Plants: Baselines for Paleodietary and Paleoecological Studies. PLoS One 8: e53763.

Szpak, P., Millaire, J.-F., White, C.D., Bourget, S., Longstaffe, F.J. In Press. Life Histories of Sacrificed Camelids from Huancaco (Virú Valley), pp. in Klaus, H.D., Toyne, J.M. (eds.), Reconstructing Sacrifice on the North Coast of Peru: Archaeological Studies of Ritual Violence in the Ancient Andes, Austin: University of Texas Press.

Szpak, P., Millaire, J.-F., White, C.D., Lau, G.F., Surette, F., Longstaffe, F.J. 2015. Origins of Prehispanic Camelid Wool Textiles from the North and Central Coasts of Peru traced by Carbon and Nitrogen Isotopic Analyses. Current Anthropology In Press.

Thornton, E.K., deFrance, S.D., Krigbaum, J., Williams, P.R. 2011. Isotopic evidence for Middle Horizon to 16th century camelid herding in the Osmore Valley, Peru. International Journal of Osteoarchaeology 21: 544-567.

Troll, C. 1968. The cordilleras of the tropical Americas, pp. 15-56 in Troll, C. (ed.) Geoecology of the Mountainous Regions of the Tropical Americas. Proceedings of the UNESCO Mexico Symposium Colloqium Geographicum Volume 9, Bonn: Geographisches Institut der Universtat.

Vallières, C. 2012. A Taste of Tiwanaku: Daily Life in an Ancient Andean Urban Center as Seen through Cuisine. Unpublished Ph.D. Dissertation, McGill University.

Vásquez, V., Rosales, T. 2012. Informe final: análisis de restos de fauna y botánicos de Caylán, valle de Nepeña. Lima, Peru: Arqueobios centros de investigaciones arqueobiológicas y paleoecológicas andinas.

Verano, J.W., DeNiro, M.J. 1993. Locals or foreigners? Morphological, biometric and isotopic approaches to the question of group affinity in human skeletal remains recovered from unusual archaeological context, pp. 361-386 in Sandford, M.K. (ed.) Investigations of Ancient Human Tissue: Chemical Analysis in Anthropology, Langhorne: Gordon and Breach.

855 Webster, A.D., Janusek, J.W. 2003. Tiwanaku camelids: Subsistence, sacrifice, and social 856 reproduction, pp. 343-362 in Kolata, A.L. (ed.) Tiwanaku and Its Hinterland: Archaeological 
and Paleoecological Investigations of an Andean Civilization: Volume 2, Urban and Rural Archaeology, Washington, D.C.: Smithsonian Institution Press.

859 Wheeler, J.C. 1985. De la chasse a l'élevage, pp. 61-79 in Lavallé, D., Julien, M., Wheeler, J.C., 860 Karlin, C. (eds.), Telarmachay: Chasseurs et Pasteurs Préhistoriques des Andes I, Vol. 1, 861 Paris, France: Institut Français d'Études Andines, Editions Recherches sur les Civilizations.

862 Wheeler, J.C. 1995. Evolution and present situation of the South American Camelidae. 863 Biological Journal of the Linnean Society 54: 271-295.

864 Wilcox, B.P., Bryant, F.C., Fraga, V.B. 1987. An Evaluation of Range Condition on One Range 865 Site in the Andes of Central Peru. Journal of Range Management 40: 41-45.

866 Wild, E.M., Arlamovsky, K.A., Golser, R., Kutschera, W., Priller, A., Puchegger, S., Rom, W., Steier, P., Vycudilik, W. 2000. ${ }^{14} \mathrm{C}$ dating with the bomb peak: An application to forensic medicine. Nuclear Instruments and Methods in Physics Research Section B: Beam Interactions with Materials and Atoms 172: 944-950.

870 Wilson, D.J. 1988. Prehispanic settlement patterns in the lower Santa Valley, Peru: A regional perspective on the origins and development of complex North Coast society. Washington,

873 Winterhalder, B., Larsen, R., Thomas, R.B. 1974. Dung as an essential resource in a highland 874 Peruvian community. Human Ecology 2: 89-104.

875 Yakir, D. 2011. The paper trail of the ${ }^{13} \mathrm{C}$ of atmospheric $\mathrm{CO}_{2}$ since the industrial revolution 876 period. Environmental Research Letters 6: 034007.

877 Zárate, A.d. 1555. Historia del desumrimiento y conquista de la Provincia del Perú. Biblioteca de 878 Autores Españoles 26: 459-574.

879 Zeder, M.A. 1991. Feeding Cities: Specialized Animal Economy in the Ancient Near East. 880 Washington, D.C.: Smithsonian Institution Press. 


\section{Figure Captions}

Figure 1. (A) Predicted average carbon and nitrogen isotopic compositions (approximating bivariate means with correlation as in the standard ellipse, see Jackson et al. 2011) of four camelids raised under four different foddering regimes. Note that it is not expected that all individuals from a given group will fall into these areas, but that a group of animals foddered under a particular set of conditions will resemble this general pattern. (B) Predicated contribution of $\mathrm{C}_{4}$ plants for the four camelid groups $\left(\mathrm{WCV}=\right.$ wild coastal vegetation, $\mathrm{C}_{4} \mathrm{C}=$ cultivated $\mathrm{C}_{4}$ crops, $\mathrm{MXC}=$ mixed irrigated cultigens, $\mathrm{C}_{3} \mathrm{P}=\mathrm{C}_{3}$ pastures). Outputs approximate probability histograms generated using the Bayesian mixing model SIAR (Parnell et al. 2010).

Figure 2. (A) Map of the Nepeña Valley and the location of Caylan and Huambacho in relation to other Early Horizon sites. (B) Map of Peru showing coastal river valleys and archaeological sites mentioned in the text.

901

902

903

904

905

Figure 3. Chronology for the Initial Period and Early Horizon in the Nepeña Valley (Shibata 2010) presented alongside the widely utilized chronological divisions in Peruvian prehistory (EIP=Early Intermediate Period, LIP=Late Intermediate Period). Approximate temporal positions of major archaeological cultures or material culture traditions mentioned in the text are also presented.

Figure 4. Site map of Caylán showing excavation units and architectural contexts excavated in 2009 and 2010. The architectural context of each sample is given in Table 1.

Figure 5. Individual carbon and nitrogen isotopic compositions for Nepeña (circles for Caylán and triangles for Huambacho) camelids plotted relative to heat maps generated on the basis of previously measured camelids from modern highland pastures and archaeological sites (A) and camelids from coastal archaeological sites (B). To generate the heat maps, data from previous studies were binned according to $1 \% \times 1 \%$ units.

Figure 6. SIAR density histograms showing estimated contributions of $\mathrm{C}_{3}$ and $\mathrm{C}_{4}$ plants for Nepeña (Caylán and Huambacho) camelids (middle panels) relative to highland camelids from a Middle Horizon site in the Callejón de Huaylas region (Chinchawas, top panel) and coastal camelids from an Early Intermediate Period site in the Virú Valley (Huaca Gallinazo, lower panel). In the second panel, three camelids with $\delta^{13} \mathrm{C}$ values $>-16 \%$ are excluded. 


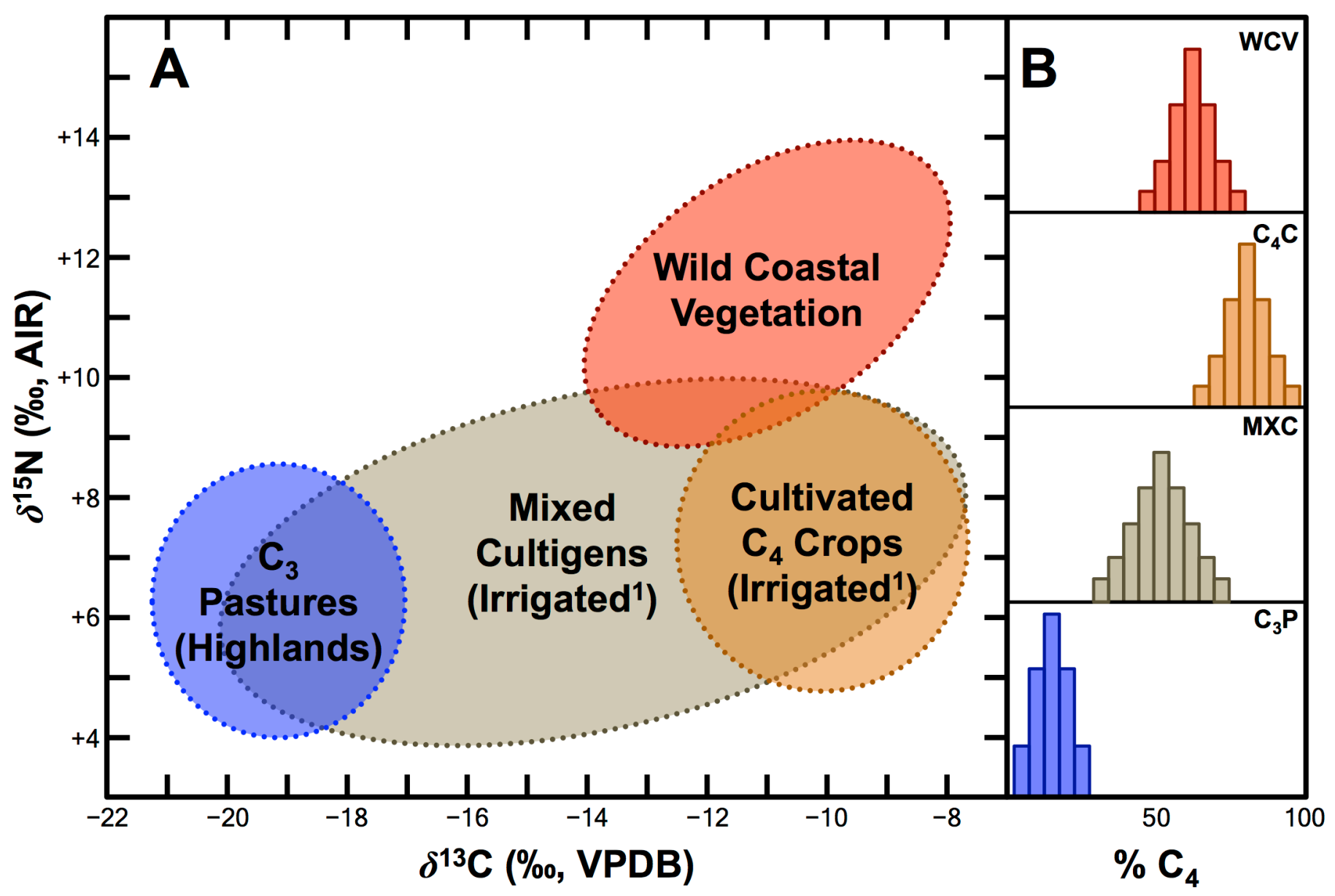




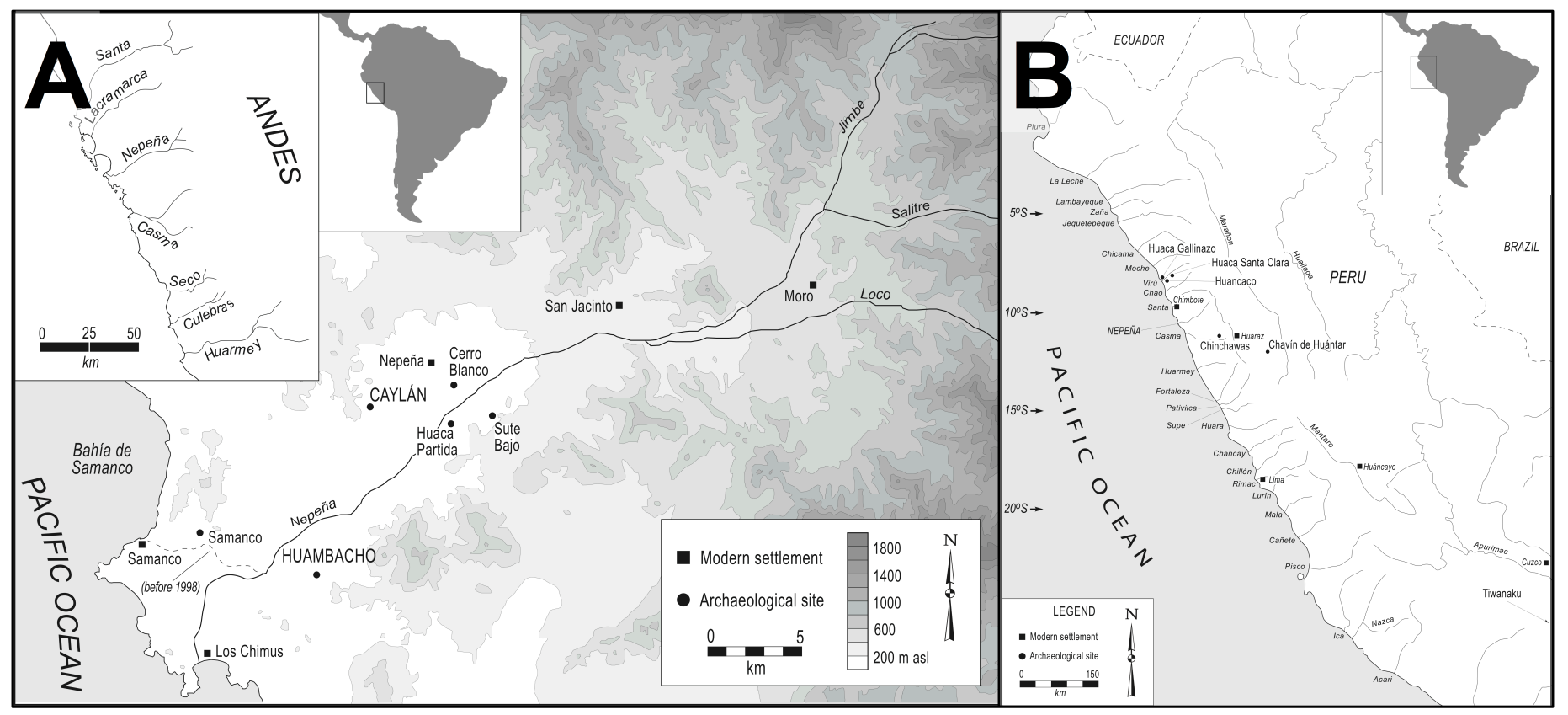




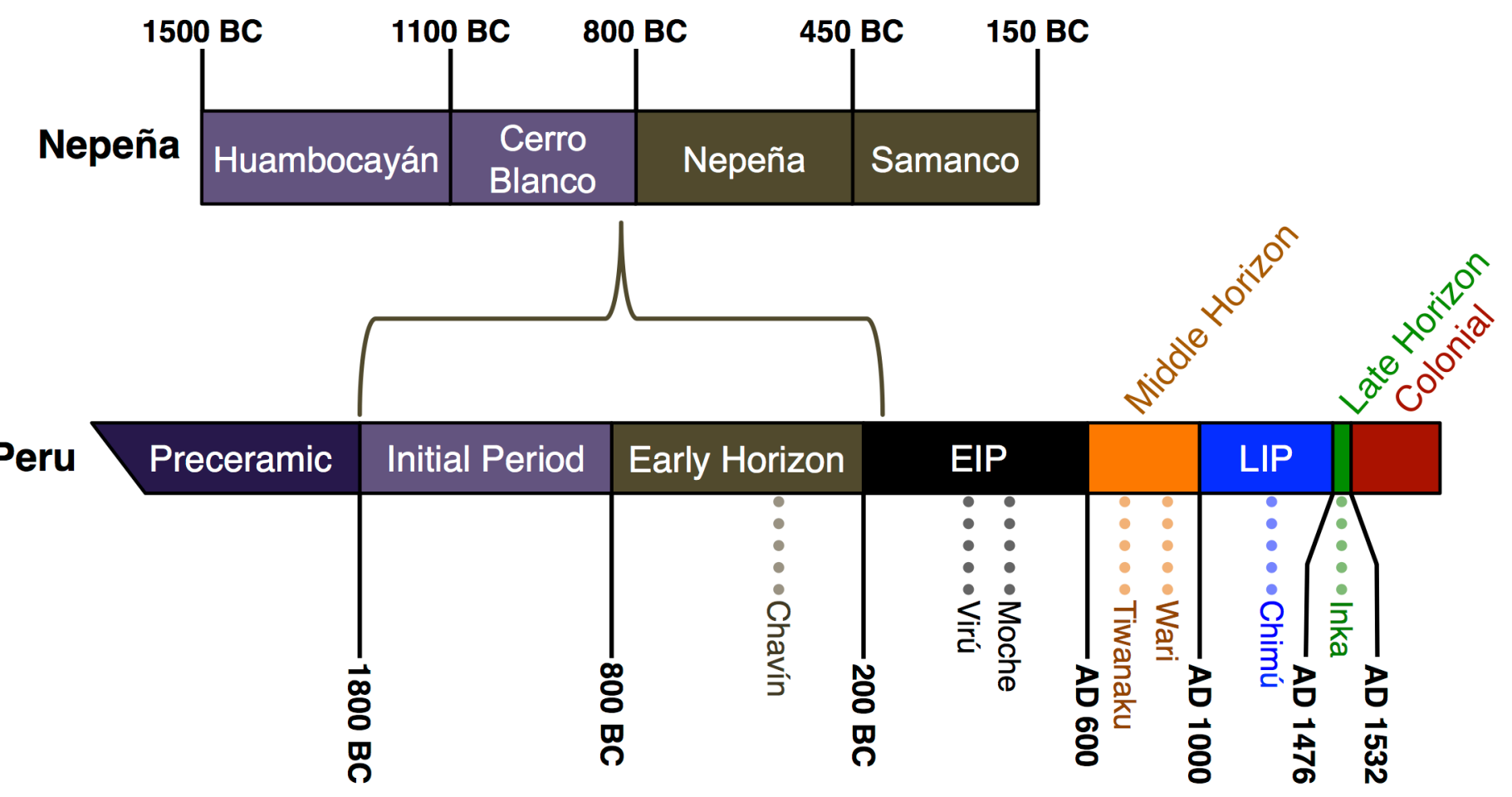




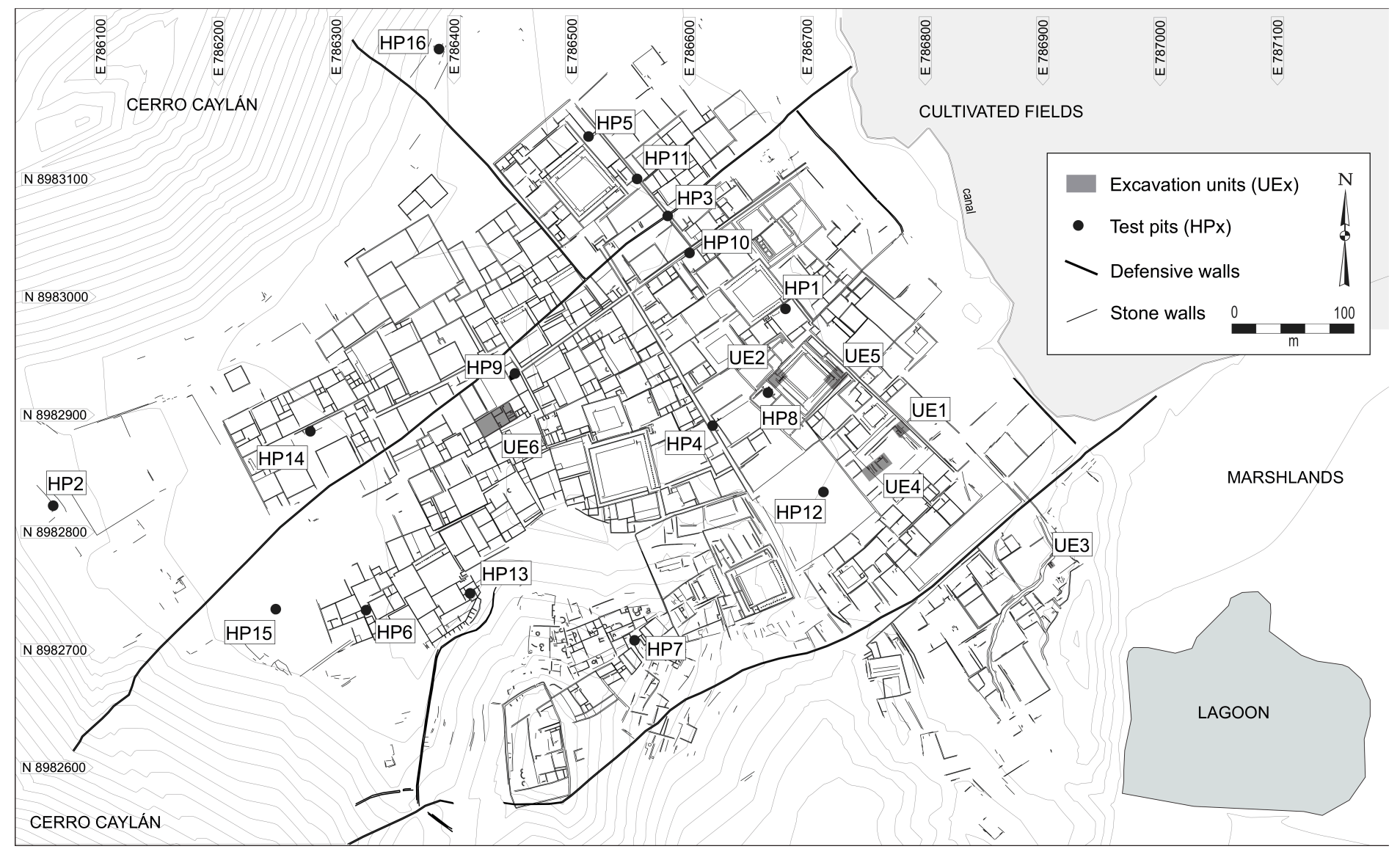




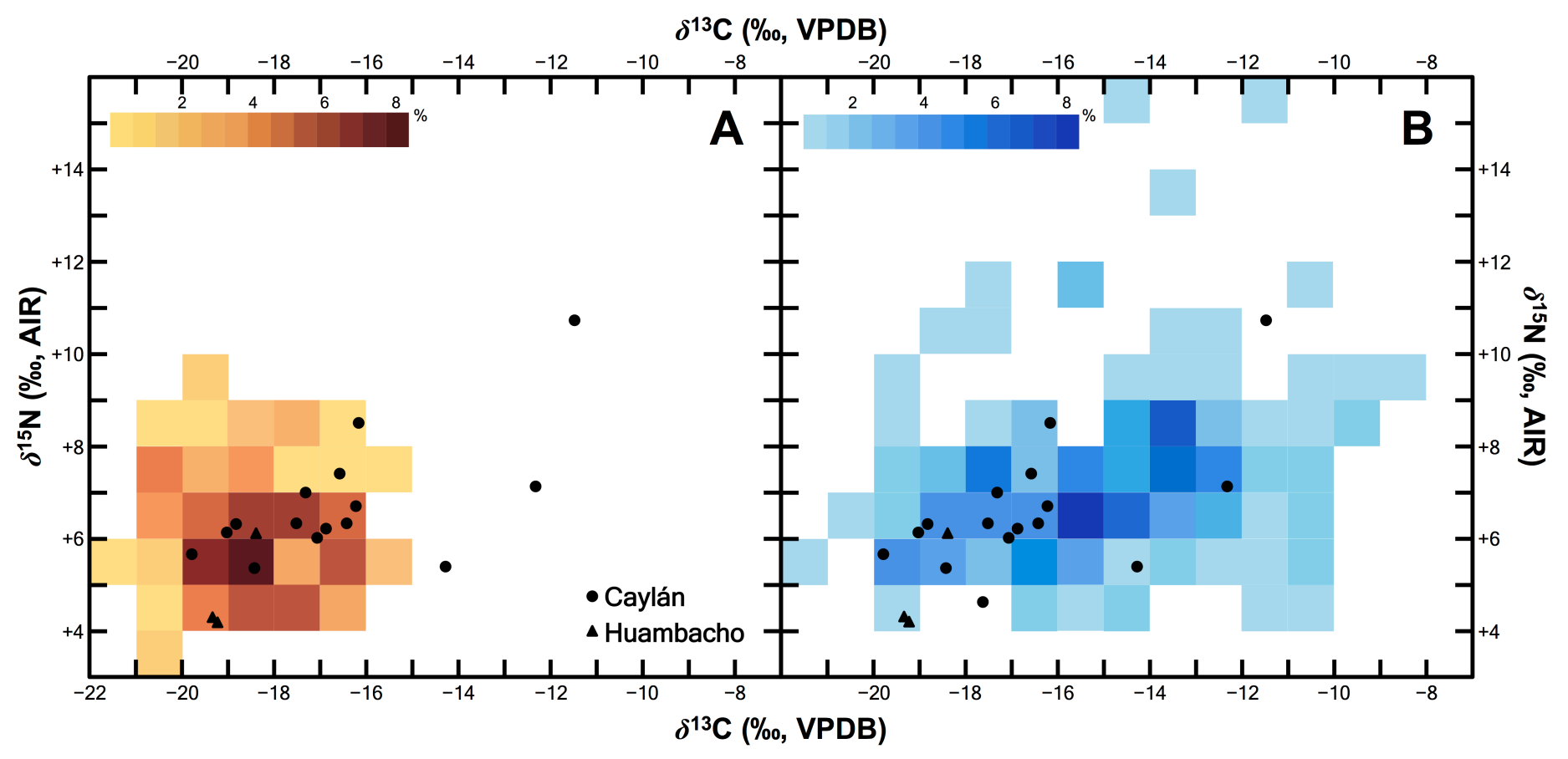




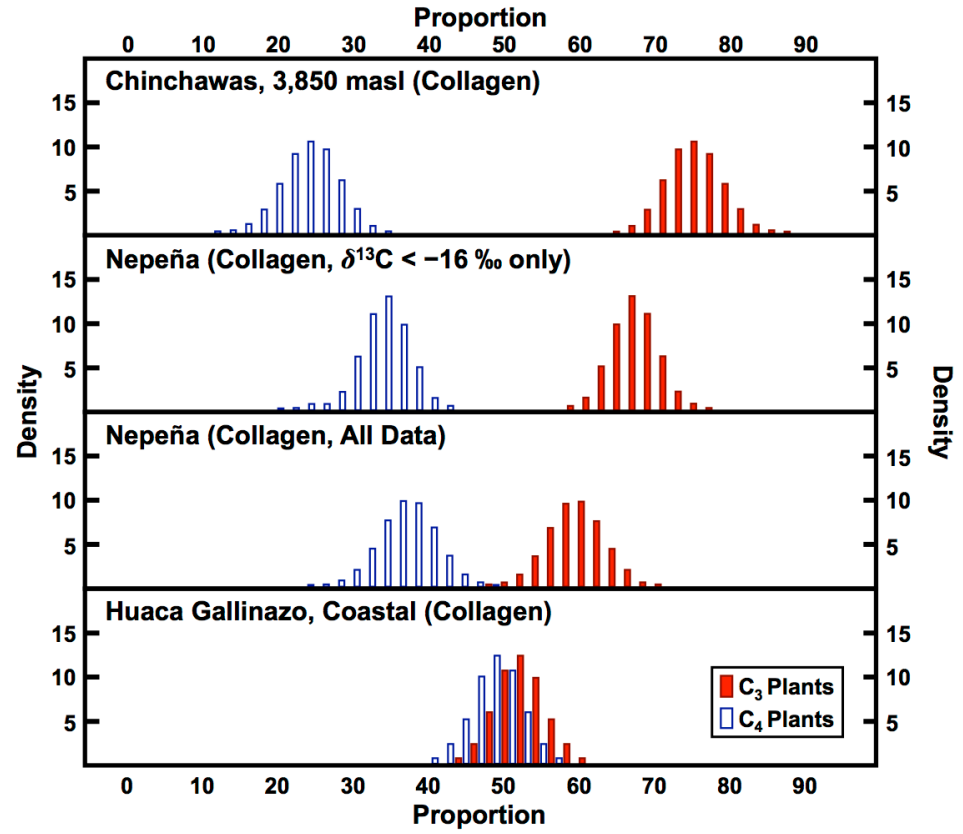


919 Table 1. Isotopic and elemental compositions for Early Horizon camelids from Caylán and 920 Humabacho. Specimens that have produced collagen deemed unreliable have been struck 921 through.

\begin{tabular}{|c|c|c|c|c|c|c|c|c|c|c|c|}
\hline Context & Unit & Room & Stratum & Element & Sample \# & $\begin{array}{l}\delta^{13} \mathrm{C} \\
(\%, \\
\text { VDPB) }\end{array}$ & $\begin{array}{l}\delta^{15} \mathbf{N} \\
(\%, \\
\text { AIR) }\end{array}$ & $\% \mathrm{C}$ & $\% \mathbf{N}$ & $\mathrm{C}: \mathrm{N}$ & $\begin{array}{l}\% \\
\text { Collagen }\end{array}$ \\
\hline \multicolumn{12}{|l|}{ Caylán } \\
\hline Mound A & UE4 & Mound A & 1 & $1^{\text {st }}$ Phalanx & AIS 1298 & -16.59 & 7.45 & 46.1 & 16.8 & 3.2 & 13.6 \\
\hline Mound A & UE4 & Terrace 2 & 1 & $1^{\text {st }}$ Phalanx & AIS 1301 & -18.46 & 5.39 & 35.8 & 12.7 & 3.3 & 2.8 \\
\hline Mound A & UE4 & Top of Mound & 2 & $1^{\text {st }}$ Phalanx & AIS 1310 & -12.31 & 7.16 & 40.7 & 14.8 & 3.2 & 16.7 \\
\hline Mound A & UE4 & Top of Mound & 4 & $\begin{array}{l}\text { Metatarsal } \\
\text { (Distal) }\end{array}$ & AIS 1313 & 15.17 & 13.36 & 22.3 & 5.1 & 5.1 & 0.7 \\
\hline Mound A & UE4 & Ext1 & 1 & $1^{\text {st }}$ Phalanx & AIS 2593 & -17.65 & 4.65 & 43.0 & 15.3 & 3.3 & 13.0 \\
\hline Mound A & UE4 & Top of Mound & 4 & $1^{\text {st }}$ Phalanx & AIS 1308 & -16.24 & 6.75 & 47.1 & 17.5 & 3.1 & 12.9 \\
\hline Mound A & UE4 & Terrace 4 & 3 & $1^{\text {st }}$ Phalanx & AIS 1316 & -18.85 & 6.33 & 43.9 & 15.9 & 3.2 & 13.0 \\
\hline Plaza A & UE5 & Plaza A & 2 & $\begin{array}{l}\text { Metatarsal } \\
\text { (Distal) }\end{array}$ & AIS 1299 & -13.93 & 16.33 & 26.5 & 5.10 & 6.1 & 0.4 \\
\hline Plaza A & UE5 & Plaza A & 2 & $1^{\text {st }}$ Phalanx & AIS 1300 & -17.32 & 7.02 & 47.5 & 17.6 & 3.1 & 20.8 \\
\hline Plaza A & HP8 & Plaza A & 2 & $1^{\text {st }}$ Phalanx & AIS 1306 & -17.53 & 6.38 & 46.5 & 17.1 & 3.2 & 16.3 \\
\hline Plaza A & UE2 & Plaza A & 5 & $1^{\text {st }}$ Phalanx & AIS 1312 & -16.20 & 8.55 & 35.8 & 12.3 & 3.4 & 1.1 \\
\hline Plaza A & UE5 & Plaza A & 1 & $1^{\text {st }}$ Phalanx & AIS 2590 & -14.28 & 5.40 & 35.2 & 12.5 & 3.3 & 6.6 \\
\hline Compound E & UE6 & $\operatorname{Rec} 5$ & 3 & $1^{\text {st }}$ Phalanx & AIS 1305 & -19.02 & 6.17 & 42.3 & 15.4 & 3.2 & 10.6 \\
\hline Compound E & UE6 & Rec6 & 3 & $1^{\text {st }}$ Phalanx & AIS 1307 & -16.89 & 6.22 & 46.1 & 17.1 & 3.2 & 13.3 \\
\hline Compound E & UE6 & Rec6 & 3 & $1^{\text {st }}$ Phalanx & AIS 1309 & -17.05 & 6.04 & 39.5 & 14.3 & 3.2 & 6.1 \\
\hline Compound E & UE6 & Rec1 & 1 & $\begin{array}{l}\text { Metatarsal } \\
\text { (Distal) }\end{array}$ & AIS 1314 & -16.15 & 10.56 & 26.6 & 7.0 & 4.5 & 0.3 \\
\hline Other & UE3 & & 1 & Mandible & AIS 1297 & -19.81 & 5.69 & 39.8 & 13.9 & 3.3 & 2.9 \\
\hline Other & UE3 & & 1 & $1^{\text {st }}$ Phalanx & AIS 1315 & -11.47 & 10.77 & 45.9 & 16.8 & 3.2 & 19.4 \\
\hline Other & HP16 & & 1 & $1^{\text {st }}$ Phalanx & AIS 1303 & -16.44 & 6.37 & 42.4 & 15.1 & 3.3 & 7.4 \\
\hline \multicolumn{12}{|l|}{ Huambacho } \\
\hline Huaca A & 23 & Huaca A & Rubble & $1^{\text {st }}$ Phalanx & AIS 2591 & -19.30 & 4.23 & 41.9 & 15.1 & 3.3 & 17.0 \\
\hline Huaca A & 23 & Huaca A & $\begin{array}{l}\text { Under } \\
\text { Floor }\end{array}$ & $1^{\text {st }}$ Phalanx & AIS 2592 & -19.32 & 4.30 & 41.7 & 15.1 & 3.2 & 12.7 \\
\hline Plaza B & 25 & Plaza B & $\begin{array}{l}\text { Under } \\
\text { Floor }\end{array}$ & $1^{\text {st }}$ Phalanx & AIS 2589 & -18.40 & 6.12 & 39.9 & 14.2 & 3.3 & 6.8 \\
\hline
\end{tabular}




\section{Supplementary Material - Analytical Precision and Accuracy}

Carbon and nitrogen isotopic and elemental compositions were determined using an Isoprime continuous flow mass spectrometer coupled to a Costech Elemental Analyzer at the Archaeology Isotope Laboratory (The University of British Columbia). The following standard reference materials were used for calibration of $\delta^{13} \mathrm{C}$ relative to VPDB and $\delta^{15} \mathrm{~N}$ relative to AIR (Table S1).

Table S.1. Standard reference materials used for calibration of $\delta^{13} \mathrm{C}$ relative to VPDB and $\delta^{15} \mathrm{~N}$ relative to AIR for the Delta $\mathrm{V}$.

\begin{tabular}{llll}
\hline Standard & Material & $\begin{array}{l}\text { Accepted } \delta^{13} \mathrm{C} \\
(\% \circ, \text { VPDB })\end{array}$ & $\begin{array}{l}\text { Accepted } \delta^{15} \mathrm{~N} \\
(\%,, \text { AIR })\end{array}$ \\
\hline USGS40 & Glutamic Acid & -26.389 & -4.52 \\
USGS41 & Glutamic Acid & +37.626 & +47.57 \\
\hline
\end{tabular}

The following internal standards were used to monitor accuracy and precision (Table S2).

The isotopic compositions reported here represent long term averages: methionine $(n=349)$, NIST 1577c $(n=195)$, SUBC-1 $(n=270)$, SRM-1 $(n=132)$, and SRM-2 $(n=119)$.

Table S.2. Standard reference materials used for to monitor internal accuracy and precision.

\begin{tabular}{llll}
\hline Standard & Material & $\begin{array}{l}\text { Accepted } \delta^{13} \mathrm{C} \\
(\% \circ, \text { VPDB })\end{array}$ & $\begin{array}{l}\text { Accepted } \delta^{15} \mathrm{~N} \\
(\% \circ, \text { AIR })\end{array}$ \\
\hline MET & Methionine & $-28.60 \pm 0.08$ & $-5.04 \pm 0.15$ \\
NIST 1577c & Bovine liver & $-17.51 \pm 0.10$ & $+8.15 \pm 0.15$ \\
SUBC-1 & Seal bone collagen & $-13.67 \pm 0.11$ & $+17.39 \pm 0.14$ \\
SRM-1 & Caribou bone collagen & $-19.31 \pm 0.11$ & $+1.81 \pm 0.11$ \\
SRM-2 & Walrus bone collagen & $-14.70 \pm 0.12$ & $+15.58 \pm 0.10$ \\
\hline
\end{tabular}

Table S3 summarizes the mean and standard deviation of carbon and nitrogen isotopic compositions for all check standards, as well as the standard deviation for all calibration 
standards - the mean of the calibration standard for an individual run is predetermined to calibrate the data.

Table S3. Accuracy and precision of calibration and check standards for all analytical sessions.

\begin{tabular}{|c|c|c|c|c|c|}
\hline Standard & Type & Run ID & $n$ & $\delta^{13} \mathrm{C}(\%, \mathrm{VPDB})$ & $\delta^{15} \mathrm{~N}(\%, \mathrm{AIR})$ \\
\hline MET & Check & G15-11 & 8 & $-28.55 \pm 0.08$ & $-5.01 \pm 0.19$ \\
\hline NIST $1577 \mathrm{c}$ & Check & G15-11 & 4 & $-17.44 \pm 0.04$ & $+8.32 \pm 0.16$ \\
\hline SUBC-1 & Check & G15-11 & 6 & $-13.62 \pm 0.12$ & $+17.36 \pm 0.08$ \\
\hline USGS40 & Calibration & G15-11 & 7 & \pm 0.14 & \pm 0.09 \\
\hline USGS41 & Calibration & G15-11 & 7 & \pm 0.18 & \pm 0.17 \\
\hline MET & Check & G15-12 & 7 & $-28.57 \pm 0.05$ & $-5.10 \pm 0.18$ \\
\hline NIST $1577 \mathrm{c}$ & Check & G15-12 & 6 & $-17.51 \pm 0.04$ & $+8.15 \pm 0.12$ \\
\hline SUBC-1 & Check & G15-12 & 6 & $-13.69 \pm 0.11$ & $+17.35 \pm 0.10$ \\
\hline USGS40 & Calibration & G15-12 & 8 & \pm 0.07 & \pm 0.14 \\
\hline USGS41 & Calibration & G15-12 & 7 & \pm 0.11 & \pm 0.31 \\
\hline NIST $1577 \mathrm{c}$ & Check & G15-13 & 5 & $-17.57 \pm 0.03$ & $+8.08 \pm 0.08$ \\
\hline SUBC-1 & Check & G15-13 & 6 & $-13.66 \pm 0.08$ & $+17.37 \pm 0.10$ \\
\hline USGS40 & Calibration & G15-13 & 9 & \pm 0.06 & \pm 0.14 \\
\hline USGS41 & Calibration & G15-13 & 9 & \pm 0.22 & \pm 0.07 \\
\hline MET & Check & G15-14 & 7 & $-28.58 \pm 0.07$ & $-4.94 \pm 0.08$ \\
\hline NIST $1577 \mathrm{c}$ & Check & G15-14 & 5 & $-17.61 \pm 0.17$ & $8.18 \pm 0.12$ \\
\hline SUBC-1 & Check & G15-14 & 4 & $-13.57 \pm 0.05$ & $+17.40 \pm 0.04$ \\
\hline USGS40 & Calibration & G15-14 & 9 & \pm 0.13 & \pm 0.22 \\
\hline USGS41 & Calibration & G15-14 & 7 & \pm 0.15 & \pm 0.03 \\
\hline MET & Check & G15-15 & 7 & $-28.62 \pm 0.06$ & $-5.03 \pm 0.10$ \\
\hline NIST $1577 \mathrm{c}$ & Check & G15-15 & 5 & $-17.57 \pm 0.08$ & $+8.22 \pm 0.06$ \\
\hline SRM-2 & Check & G15-15 & 2 & $-14.96 \pm 0.01$ & $+15.71 \pm 0.03$ \\
\hline SUBC-1 & Check & G15-15 & 4 & $-13.70 \pm 0.12$ & $+17.28 \pm 0.15$ \\
\hline USGS40 & Calibration & G15-15 & 9 & \pm 0.08 & \pm 0.16 \\
\hline USGS41 & Calibration & G15-15 & 9 & \pm 0.23 & \pm 0.19 \\
\hline MET & Check & G15-16 & 7 & $-28.64 \pm 0.06$ & $-5.01 \pm 0.14$ \\
\hline NIST 1577c & Check & G15-16 & 5 & $-17.52 \pm 0.06$ & $+8.11 \pm 0.18$ \\
\hline SUBC-1 & Check & G15-16 & 6 & $-13.61 \pm 0.04$ & $+17.38 \pm 0.08$ \\
\hline USGS40 & Calibration & G15-16 & 9 & \pm 0.05 & \pm 0.11 \\
\hline USGS41 & Calibration & G15-16 & 9 & \pm 0.13 & \pm 0.14 \\
\hline MET & Check & G15-19 & 7 & $-28.63 \pm 0.03$ & $-5.16 \pm 0.20$ \\
\hline NIST 1577c & Check & G15-19 & 5 & $-17.53 \pm 0.02$ & $+8.13 \pm 0.04$ \\
\hline SUBC-1 & Check & G15-19 & 6 & $-13.65 \pm 0.09$ & $+17.35 \pm 0.06$ \\
\hline USGS40 & Calibration & G15-19 & 9 & \pm 0.06 & \pm 0.05 \\
\hline USGS41 & Calibration & G15-19 & 9 & \pm 0.17 & \pm 0.07 \\
\hline MET & Check & G15-21 & 7 & $-28.62 \pm 0.06$ & $-5.08 \pm 0.22$ \\
\hline NIST 1577c & Check & G15-21 & 5 & $-17.52 \pm 0.07$ & $+8.23 \pm 0.09$ \\
\hline SUBC-1 & Check & G15-21 & 6 & $-13.67 \pm 0.08$ & $+17.41 \pm 0.10$ \\
\hline 40 & Calibration & G15-21 & 9 & \pm 0.04 & 06 \\
\hline
\end{tabular}




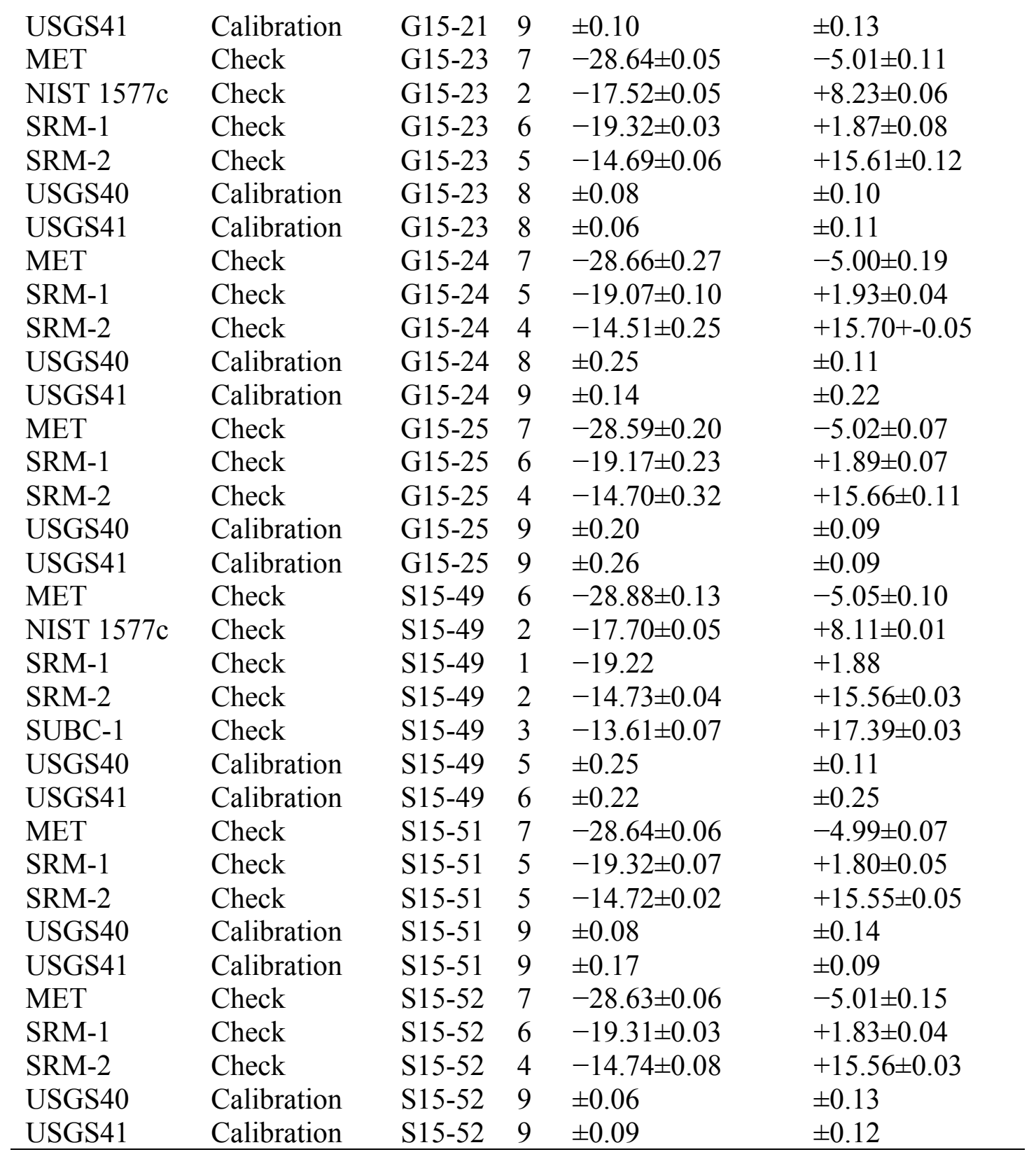

At least ten percent of all samples were analyzed in duplicate to monitor for accuracy and precision ( 3 duplicates). For these replicates, the mean difference between pairs was 0.07 $\%$ for $\delta^{13} \mathrm{C}$ and $0.02 \%$ for $\delta^{15} \mathrm{~N}$. These results are presented in full in Table S4. The boldface number in parentheses beside the first $\delta^{13} \mathrm{C}$ or $\delta^{15} \mathrm{~N}$ value for each duplicate pair represents the difference between the two measurements for that sample. 
Table S4. Carbon and nitrogen isotopic compositions for all duplicate sample pairs analyzed. Numbers in parentheses indicate differences between duplicates.

\begin{tabular}{lll}
\hline Sample ID & $\boldsymbol{\delta}^{\mathbf{1 3}} \mathbf{C}(\mathbf{\% o}, \mathbf{V P D B})$ & $\boldsymbol{\delta}^{\mathbf{1 5}} \mathbf{N}(\mathbf{\% o}, \mathbf{A I R})$ \\
\hline AIS 1305 & $-11.68(\mathbf{0 . 0 4})$ & $+10.77(\mathbf{0 . 0 3})$ \\
AIS 1305 DUP & -11.64 & +10.80 \\
AIS 1315 & $-18.87(\mathbf{0 . 1 5})$ & $+6.17(\mathbf{0 . 0 3})$ \\
AIS 1315 DUP & -19.02 & +6.20 \\
AIS 2592 & $-19.32(\mathbf{0 . 0 2})$ & $+4.30(<\mathbf{0 . 0 1})$ \\
AIS 2592 DUP & -19.30 & +4.30 \\
\hline
\end{tabular}

